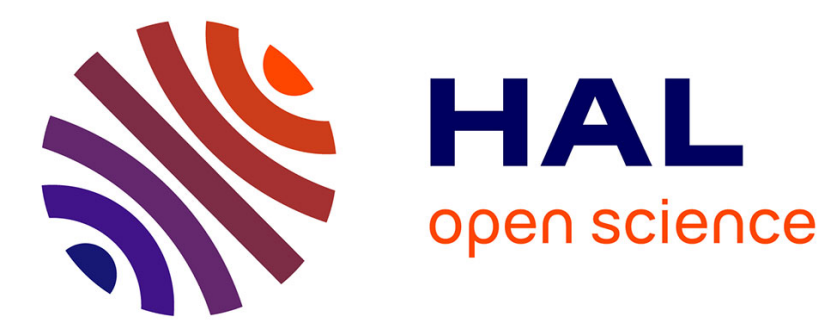

\title{
Mechanistic insights into antitumor effects of new dinuclear cis Pt complexes containing aromatic linkers
}

\author{
Lenka Zerzankova, Hana Kostrhunova, Marie Vojtiskova, Olga Novakova,
} Tereza Suchankova, Miaoxin Lin, Zijian Guo, Jana Kasparkova, Viktor Brabec

\section{- To cite this version:}

Lenka Zerzankova, Hana Kostrhunova, Marie Vojtiskova, Olga Novakova, Tereza Suchankova, et al.. Mechanistic insights into antitumor effects of new dinuclear cis Pt complexes containing aromatic linkers. Biochemical Pharmacology, 2010, 80 (3), pp.344. 10.1016/j.bcp.2010.04.013 . hal-00596277

\section{HAL Id: hal-00596277 \\ https://hal.science/hal-00596277}

Submitted on 27 May 2011

HAL is a multi-disciplinary open access archive for the deposit and dissemination of scientific research documents, whether they are published or not. The documents may come from teaching and research institutions in France or abroad, or from public or private research centers.
L'archive ouverte pluridisciplinaire HAL, est destinée au dépôt et à la diffusion de documents scientifiques de niveau recherche, publiés ou non, émanant des établissements d'enseignement et de recherche français ou étrangers, des laboratoires publics ou privés. 


\section{Accepted Manuscript}

Title: Mechanistic insights into antitumor effects of new dinuclear cis $\mathrm{Pt}^{I I}$ complexes containing aromatic linkers

Authors: Lenka Zerzankova, Hana Kostrhunova, Marie Vojtiskova, Olga Novakova, Tereza Suchankova, Miaoxin Lin, Zijian Guo, Jana Kasparkova, Viktor Brabec

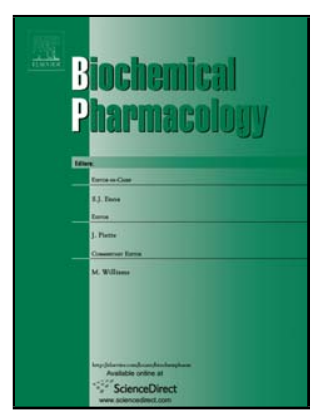

PII: S0006-2952(10)00258-3

DOI: doi:10.1016/j.bcp.2010.04.013

Reference: BCP 10530

To appear in: $\quad B C P$

Received date: $\quad$ 6-3-2010

Revised date: $\quad 7-4-2010$

Accepted date: $\quad 9-4-2010$

Please cite this article as: Zerzankova L, Kostrhunova H, Vojtiskova M, Novakova O, Suchankova T, Lin M, Guo Z, Kasparkova J, Brabec V, Mechanistic insights into antitumor effects of new dinuclear cis $\mathrm{Pt}^{I I}$ complexes containing aromatic linkers, Biochemical Pharmacology (2008), doi:10.1016/j.bcp.2010.04.013

This is a PDF file of an unedited manuscript that has been accepted for publication. As a service to our customers we are providing this early version of the manuscript. The manuscript will undergo copyediting, typesetting, and review of the resulting proof before it is published in its final form. Please note that during the production process errors may be discovered which could affect the content, and all legal disclaimers that apply to the journal pertain. 


\section{Mechanistic insights into antitumor effects of new dinuclear cis}

\section{$\mathrm{Pt}^{\mathrm{II}}$ complexes containing aromatic linkers}

Lenka Zerzankova $^{\text {a }}$, Hana Kostrhunova ${ }^{\text {a, }}$ Marie Vojtiskova ${ }^{\text {a }}$, Olga Novakova a ,

Tereza Suchankova ${ }^{\mathrm{b}}$, Miaoxin Lin ${ }^{\mathrm{c}}$, Zijian Guo $^{\mathrm{c}}$, Jana Kasparkova ${ }^{\mathrm{a}, *}$

Viktor Brabec ${ }^{\mathrm{a}, *}$

${ }^{a}$ Institute of Biophysics, Academy of Sciences of the Czech Republic, v.v.i., CZ-61265 Brno,

Czech Republic

${ }^{b}$ Department of Experimental Physics, Faculty of Sciences, Palacky University, tr. Svobody 26, 77146 Olomouc, Czech Republic

${ }^{c}$ State Key Laboratory of Coordination Chemistry, School of Chemistry and Chemical Engineering, Nanjing University, Nanjing 210093, PR China

Classification: (1) Antibiotics and Chemotherapeutics

* Corresponding authors at: Institute of Biophysics, Academy of Sciences of the Czech Republic, v.v.i., Kralovopolska 135, CZ-61265 Brno, Czech Republic. Tel.: +420-541517148; fax: $+420-541240499$.

E-mail addresses: jana@ibp.cz (J. Kasparkova); brabec@ibp.cz (V. Brabec) 
Abbreviations: BBR3464, [\{trans-PtCl( $\left.\left(\mathrm{NH}_{3}\right)_{2}\right\}_{2}-\mu-$ trans $\left.-\mathrm{Pt}\left(\mathrm{NH}_{3}\right)_{2}\left(\mathrm{NH}_{2}\left(\mathrm{CH}_{2}\right)_{6} \mathrm{NH}_{2}\right)_{2}\right]^{4+}$; BBR3610, [ $\left\{\text { trans-PtCl }\left(\mathrm{NH}_{3}\right)_{2}\right\}_{2}-\mu-\left\{\text { trans }-\left(\mathrm{H}_{2} \mathrm{~N}\left(\mathrm{CH}_{2}\right)_{6} \mathrm{NH}_{2}\left(\mathrm{CH}_{2}\right)_{2} \mathrm{NH}_{2}\left(\mathrm{CH}_{2}\right)_{6} \mathrm{NH}_{2}\right\}\right]^{4+} ; \mathrm{bp}$, base pair; cisplatin, cis-diamminedichloroplatinum(II); CFE, cell-free extract; CL, crosslink; complex 1, $\left\{\left[\text { cis-Pt }\left(\mathrm{NH}_{3}\right)_{2} \mathrm{Cl}\right]_{2}\left(4,4^{\prime}-\text { methylenedianiline }\right)\right\}^{2+}$; complex 2, $\{[$ cis$\left.\mathrm{Pt}\left(\mathrm{NH}_{3}\right)_{2} \mathrm{Cl}\right]_{2}\left(\alpha, \alpha^{\prime}\right.$-diamino-p-xylene $\left.)\right\}^{2+} ; \mathrm{CT}$, calf-thymus; DPP, differential pulse polarography; EtBr, ethidium bromide; FAAS, flameless atomic absorption spectrophotometry; $\mathrm{HMG}$, high-mobility-group; $\mathrm{IC}_{50}$, concentration inhibiting cell growth by 50\%; MTT, [3-(4,5-dimethylthiazol-2-yl)-2,5-diphenyltetrazolium bromide]; PAGE, polyacrylamide gel electrophoresis; $r_{\mathrm{b}}$, the number of molecules of the metal complex bound per nucleotide residue; $r_{\mathrm{i}}$, the molar ratio of free metal complex to nucleotide-phosphates at the onset of incubation with DNA; SDS, sodium dodecyl sulfate. 


\begin{abstract}
The primary objective was to understand more deeply the molecular mechanism underlying different antitumor effects of dinuclear $\mathrm{Pt}^{\mathrm{II}}$ complexes containing aromatic linkers of different length, $\left\{\left[\text { cis-Pt }\left(\mathrm{NH}_{3}\right)_{2} \mathrm{Cl}\right]_{2}\left(4,4^{\prime}-\text { methylenedianiline }\right)\right\}^{2+}(\mathbf{1})$ and $\left\{\left[\text { cis-Pt }\left(\mathrm{NH}_{3}\right)_{2} \mathrm{Cl}\right]_{2}\left(\alpha, \alpha^{\prime}-\right.\right.$ diamino-p-xylene) $\}^{2+}(\mathbf{2})$. These complexes belong to a new generation of promising polynuclear platinum drugs resistant to decomposition by sulfur nucleophiles which hampers clinical use of bifunctional polynuclear trans $\mathrm{Pt}^{\mathrm{II}}$ complexes hitherto tested. Results obtained with the aid of methods of molecular biophysics and pharmacology reveal differences and new details of DNA modifications by $\mathbf{1}$ and $\mathbf{2}$ and recognition of these modifications by cellular components. The results indicate that the unique properties of DNA interstrand crosslinks of this class of polynuclear platinum complexes and recognition of these cross-links may play a prevalent role in antitumor effects of these metallodrugs. Moreover, the results show for the first time a strong specific recognition and binding of high-mobility-group domain proteins, which are known to modulate antitumor effects of clinically used platinum drugs, to DNA modified by a polynuclear platinum complex.
\end{abstract}

Key words: dinuclear platinum; antitumor; DNA damage; interstrand cross-link; recognition 


\section{Introduction}

The polynuclear platinum compounds represent a class of new antitumor metallodrugs that is structurally distinct from conventional cis-diamminedichloridoplatinum(II) (cisplatin) and its mononuclear analogues, and whose clinical profile and mechanism of action are different from these established platinum mononuclear compounds [1-6]. DNA adducts of polynuclear platinum complexes, whose formation is associated with antitumor effects of these agents, differ significantly in structure and type from those of mononuclear platinum complexes. Especially because of markedly more distant leaving groups, long-range intra- and interstrand crosslinks (CLs) are formed in DNA which affect DNA conformation, are recognized by specific proteins and repaired differently in comparison with the CLs of cisplatin and its mononuclear analogues [7-11]. Importantly, cells with resistance to cisplatin showed no cross-resistance to polynuclear platinum compounds [12-14]. The polynuclear platinum complexes also exhibit significantly higher levels of cellular uptake very likely because of their lipophilic linker chains and hydrophilic platinum-amine coordination spheres, which may enhance membrane permeability $[13,15,16]$.

The biological activity of polynuclear platinum complexes may be modulated by the geometry and number of leaving groups in the coordination sphere of platinum atoms as well as by the nature of linkers connecting the platinum centers. In contrast with the mononuclear complexes, such as antitumor cisplatin and clinically ineffective transplatin, in the dinuclear case both geometries are antitumor active [2], although DNA adducts (CLs) as well as local conformational distortions on DNA and their recognition by cellular components are affected by geometry $[7,10,17]$. The dinuclear cis isomer $\left[\left\{\text { cis- } \mathrm{PtCl}\left(\mathrm{NH}_{3}\right)_{2}\right\}_{2}\left(\mathrm{H}_{2} \mathrm{~N}-\left(\mathrm{CH}_{2}\right)_{6}-\mathrm{NH}_{2}\right]^{2+}\right.$ is kinetically more inert in its reactions with DNA and in double-stranded DNA produces more interstrand crosslinks than its trans counterpart [10]. 
Also importantly, the general structure, such as $\left[\left\{\text { trans }-\mathrm{PtCl}\left(\mathrm{NH}_{3}\right)_{2}\right\}_{2}-\mu-\mathrm{Y}\right]^{n+}(\mathrm{Y}=$ $\mathrm{NH}_{2}\left(\mathrm{CH}_{2}\right)_{6} \mathrm{NH}_{2}$, spermidine, spermine (BBR3610), trans- $\mathrm{Pt}\left(\mathrm{NH}_{3}\right)_{2}\left(\mathrm{H}_{2} \mathrm{~N}\left(\mathrm{CH}_{2}\right)_{6} \mathrm{NH}_{2}\right)_{2}$ (BBR3464), etc.), is susceptible to decomposition by the sulfur nucleophiles[18] since substitution of the Pt-Cl bond by a trans-influencing S donor results in bridge cleavage [1921]. Hence, the antitumor polynuclear trans $\mathrm{Pt}^{\mathrm{II}}$ complexes, such as for instance trinuclear BBR3464 or dinuclear BR3610, undergo deactivation upon reaction with sulfur nucleophiles, which could result in decreased bioavailability, as well as in increased amounts of toxic metabolites in the host system, which may limit their clinical use [19]. On the other hand, the cis geometry as in $\left[\left\{\text { cis- } \mathrm{PtCl}\left(\mathrm{NH}_{3}\right)_{2}\right\}_{2}-\mu-\mathrm{Y}\right]^{n+}$ should preserve the main features of antitumor polynuclear $\mathrm{Pt}^{\mathrm{II}}$ complexes but with enhanced stability to metabolic deactivation.

In an effort to design a polynuclear platinum compound that maintains the target (DNA) binding profile of the cytotoxic $\mathrm{Pt}^{\mathrm{II}}$ polynuclear compounds and is less susceptible to metabolic decomposition, the long-chain bifunctional dinuclear cis platinum complexes $\left[\{\mathrm{PtCl}(\mathrm{DACH})\}_{2}-\mu-\mathrm{H}_{2} \mathrm{~N}\left(\mathrm{CH}_{2}\right)_{6} \mathrm{NH}_{2}\left(\mathrm{CH}_{2}\right)_{2} \mathrm{NH}_{2}\left(\mathrm{CH}_{2}\right)_{6} \mathrm{NH}_{2}\right]^{4+}(\mathrm{DACH}=1,2-$ diaminocyclohexane) and $\left\{\left[\text { cis- } \mathrm{Pt}\left(\mathrm{NH}_{3}\right)_{2} \mathrm{Cl}\right]_{2}\left(4,4^{\prime}-\text {-methylenedianiline }\right)\right\}^{2+}$ (complex 1, Fig. 1) were synthesized $[22,23]$. Hence, both dinuclear cis $\mathrm{Pt}^{\mathrm{II}}$ complexes exhibit enhanced stability to metabolic deactivation $[22,23]$.

Platinum-DNA binding, recognition of platinated DNA by proteins and DNA repair are important pharmacological features dictating a platinum drug's efficacy [2, 24, 25]. As regards molecular mechanisms of antitumor polynuclear $\mathrm{Pt}^{\mathrm{II}}$ complexes, a great attention has been so far paid mostly to polynuclear trans $\mathrm{Pt}^{\mathrm{II}}$ complexes whose clinical application is limited due to their lowered stability to metabolic deactivation. Thus, the important aim of this study was to broaden theoretical background of biological (antitumor) effects of dinuclear cis $\mathrm{Pt}^{\mathrm{II}}$ complexes, which exhibit enhanced stability to metabolic deactivation. The primary objective in the present study was to understand more deeply those aspects of the molecular 
mechanism of action of the new dinuclear $c i s \mathrm{Pt}^{\mathrm{II}}$ complex $\mathbf{1}$ containing a semi-rigid linker and for comparative purposes the molecular mechanism of action of a structurally cognate dinuclear cis $\mathrm{Pt}^{\mathrm{II}}$ complex containing a shorter, more rigid linker, $\left\{\left[c i s-\mathrm{Pt}\left(\mathrm{NH}_{3}\right)_{2} \mathrm{Cl}\right]_{2}\left(\alpha, \alpha^{\prime}-\right.\right.$ diamino-p-xylene) $\}^{2+}$ (complex 2, Fig. 1) which are related to DNA modification by these complexes, recognition of these modifications by proteins and DNA repair. Here, we describe experiments revealing (i) new details of the DNA binding mode of $\mathbf{1}$ and $\mathbf{2}$ in cell-free media; (ii) repair of DNA adducts of $\mathbf{1}$ and $\mathbf{2}$ (since the integrity of this process in human cells is a key indicator of the sensitivity of a tumor to platinum-based therapy [26]); (iii) recognition of DNA adducts of $\mathbf{1}$ and $\mathbf{2}$ by high-mobility-group (HMG)-domain proteins (since these proteins are involved in the cisplatin mechanism of action [25]); (iv) sensitization of breast cancer cells to 1 and 2 by steroid hormones.

\section{Materials and methods}

\subsection{Chemicals}

Cisplatin was obtained from Sigma (Prague, Czech Republic) (purity was $\geq 99.9 \%$ based on elemental and ICP trace analysis). Dinuclear $\mathrm{Pt}^{\mathrm{II}}$ complexes $\mathbf{1}$ and $\mathbf{2}$ were prepared as described previously $[23,27]$. The stock solutions of platinum compounds were prepared in $10 \mathrm{mM} \mathrm{NaClO}_{4}$ and stored at $20^{\circ} \mathrm{C}$ in the dark. The concentrations of platinum complexes in the stock solutions were determined by flameless atomic absorption spectrometry (FAAS). The concentrations of the platinum complexes indicated in the present work are related to the whole compound (not to the Pt content in the case of the dinuclear complexes). Calf thymus (CT) DNA ( $42 \% \mathrm{G}+\mathrm{C}$, mean molecular mass ca. $20000 \mathrm{kDa})$ was prepared and 
characterized as described previously [28, 29]. Plasmids, pUC19 [2686 base pairs (bp)] and pBR322 (4361 bp) were isolated according to standard procedures. Restriction endonucleases were purchased from New England Biolabs (Beverly, MA). Deoxyribonucleoside triphosphates were from Roche Diagnostics, GmbH (Mannheim, Germany). Agarose was from FMC BioProducts (Rockland, ME). Electrophoresis-grade acrylamide, N,N'methylenebisacrylamide, ethidium bromide (EtBr), urea, and dithiothreitol were from Merck KgaA (Darmstadt, Germany). Proteinase K and ATP were from Boehringer (Mannheim, Germany). Spermine, EZBlue Gel Staining Reagent, $\beta$-estradiol and progesterone were from Sigma (Prague, Czech Republic). Expression and purification of recombinant rat full-length HMGB1 protein $(\mathrm{HMG}=$ high mobility group) and its domains A (residues 1-84 [30]) and B (residues 85-180 [30]) (HMGB1a and HMGB1b, respectively) were carried out as described [30-32]. Nonidet P-40 was from Fluka (Prague, Czech Republic). SDS was from Serva (Heidelberg, Germany). MTT [3-(4,5-dimethylthiazol-2-yl)-2,5-diphenyltetrazolium bromide] was from Calbiochem (Darmstadt, Germany). Radioactive products were from Amersham (Arlington Heights, IL, USA). A cell-free extract (CFE) was prepared from the repair proficient HeLa S3 cell line as described [33, 34]. Streptavidin-coated magnetic beads (Dynabeads) and Biotin-14-dATP were from Invitrogen Dynal AS (Oslo, Norway).

\subsection{Cytotoxicity}

Cisplatin, $\mathbf{1}$ and $\mathbf{2}$ were dissolved in DMSO. Stock solutions of the compounds were freshly prepared before use. The final concentration of DMSO in cell culture medium did not exceed $0.25 \%$. The A2780 and A2780cisR human ovarian carcinoma cell lines (parent cisplatin sensitive and with acquired cisplatin resistance, respectively) were grown in RPMI 1640 medium (GIBCO, Carlsbad, CA) supplemented with gentamycin [50 $\mu \mathrm{g} / \mathrm{mL}$, Serva 
(Heidelberg, Germany)] and 10\% heat inactivated fetal bovine serum (GIBCO, Carlsbad, CA). The acquired resistance of A2780cisR cells was maintained by supplementing the medium with $1 \mu \mathrm{M}$ cisplatin every second passage. The cells were cultured in a humidified incubator at $37^{\circ} \mathrm{C}$ in a $5 \% \mathrm{CO}_{2}$ atmosphere and subcultured 2-3 times a week with an appropriate plating density.

Cell death was evaluated by using a system based on the tetrazolium compound MTT which is reduced by living cells to yield a formazan product that can be detected colorimetrically [35]. The cells were seeded in 96-well tissue cultured plates at a density of $10^{4}$ cells/well in $100 \mu \mathrm{L}$ of medium. After overnight incubation $(16 \mathrm{hr})$, the cells were treated with the platinum compounds at the final concentrations in the range of 0 to $128 \mu \mathrm{M}$ in a final volume of $200 \mu \mathrm{L} /$ well. After additional $72 \mathrm{hr} 10 \mu \mathrm{L}$ of a freshly diluted MTT solution $(2.5$ $\mathrm{mg} / \mathrm{mL}$ ) was added to each well and the plate was incubated at $37^{\circ} \mathrm{C}$ in a humidified $5 \% \mathrm{CO}_{2}$ atmosphere for $4 \mathrm{hr}$. At the end of the incubation period the medium was removed and the formazan product was dissolved in $100 \mu \mathrm{L}$ of DMSO. The cell viability was evaluated by measurement of the absorbance at $570 \mathrm{~nm}$, using an Absorbance Reader SUNRICE TECAN SCHOELLER. IC $_{50}$ values were calculated from curves constructed by plotting cell survival $(\%)$ versus drug concentration $(\mu \mathrm{M})$. All experiments were made in triplicate. The reading values were converted to the percentage of control (\% cell survival). Cytotoxic effects were expressed as $\mathrm{IC}_{50}$ (concentration inhibiting cell growth by $50 \%$ ).

\subsection{Platination reactions in cell-free media}

If not stated otherwise, DNA was incubated with the platinum complex in $10 \mathrm{mM}$ $\mathrm{NaClO}_{4}$ at $37^{\circ} \mathrm{C}$ in the dark. After $24 \mathrm{hr}$, the samples were exhaustively dialyzed against the medium required for subsequent biochemical or biophysical analysis. An aliquot of these 
samples was used to determine the value of $r_{b}$ by FAAS. Alternatively, DNA binding of $\mathbf{1}$ and 2 was studied using differential pulse polarography (DPP) [36].

\subsection{Recognition of DNA adducts by HMG-domain protein}

The EcoRI/PvuII restriction fragment (92 bp) from pUC19 plasmid was modified with cisplatin or complexes 1 or 2 to desired $\mathrm{r}_{\mathrm{b}}$ value in $0.01 \mathrm{M} \mathrm{NaClO}_{4}$ at $37^{\circ} \mathrm{C}$, in dark for $24 \mathrm{hr}$. Following the incubation or the optional radioactive labeling (by $\gamma-{ }^{32} \mathrm{P}$ ATP), the fragments were 3 '-end biotinylated using Biotin-14-dATP label and terminal deoxynucleotidyl transferase in terminal transferase buffer $\left(100 \mathrm{mM}\right.$ cacodylate buffer, $\mathrm{pH} 6.8 ; 5 \mathrm{mM} \mathrm{CoCl}_{2}$, $0.5 \mathrm{mM}$ dithiothreitol). Biotinylated DNA was attached to streptavidine coated magnetic beads in $1 \mathrm{M} \mathrm{NaCl}, 5 \mathrm{mM}$ Tris. $\mathrm{HCl} \mathrm{pH} 7.4$ and $0.5 \mathrm{mM}$ EDTA. The beads were washed three times in the same buffer. HMG protein was added to the beads carrying DNA and incubated on ice in $10 \mathrm{mM}$ HEPES, pH 7.5, $10 \mathrm{mM} \mathrm{MgCl}_{2}, 50 \mathrm{mM} \mathrm{LiCl}, 100 \mathrm{mM} \mathrm{NaCl}, 1 \mathrm{mM}$ spermidine and $0.05 \%$ Nonidet $\mathrm{P} 40$, in the presence of poly $(\mathrm{dI}-\mathrm{dC})$ as a competitor for $1 \mathrm{hr}$. The beads were then washed 2 times in the same buffer. Finally the protein was released with $0.04 \%$ sodium dodecyl sulfate (SDS). Following the addition of loading buffer (0.1 M Tris$\mathrm{HCl}, \mathrm{pH}$ 6.8; $2 \%$ SDS; $0.1 \mathrm{M}$ dithiothreitol, $10 \%$ glycerol, $0.25 \%$ bromphenol blue) the samples were heated for five minutes at $90^{\circ} \mathrm{C}$, electrophoresed on $15 \%$ SDS-PAGE (PAGE $=$ polyacryalamide gel electrophoresis) and stained with EZBlue gel staining reagent.

\subsection{DNA repair synthesis by human cell extract}

Repair DNA synthesis of CFEs was assayed using pUC19 plasmid. Each reaction of 50 $\mu \mathrm{L}$ contained $600 \mathrm{ng}$ of nonmodified pBR322 and $600 \mathrm{ng}$ of nonmodified or platinated 
pUC19, $2 \mathrm{mM}$ ATP, $30 \mathrm{mM} \mathrm{KCl}, 0.05 \mathrm{mg} / \mathrm{mL}$ creatine phosphokinase (rabbit muscle), 20 mM each dGTP, dATP, and dTTP, $8 \mathrm{mM} \mathrm{dCTP,} 74 \mathrm{kBq}$ of $\left[\alpha^{-}{ }^{32} \mathrm{P}\right] \mathrm{dCTP}$ in the buffer composed of $40 \mathrm{mM}$ HEPES-KOH, $\mathrm{pH} 7.5,5 \mathrm{mM} \mathrm{MgCl}_{2}, 0.5 \mathrm{mM}$ dithiothreitol, $22 \mathrm{mM}$ creatine phosphate, $1.4 \mathrm{mg}$ of bovine serum albumin/mL, and $20 \mu \mathrm{g}$ of CFE from the HeLa S3 cells. Reactions were incubated for $3 \mathrm{hr}$ at $30^{\circ} \mathrm{C}$ and terminated by adding EDTA to a final concentration of $20 \mathrm{mM}$, SDS to $0.6 \%$, and proteinase $\mathrm{K}$ to $250 \mu \mathrm{g} / \mathrm{mL}$ and then incubating for $20 \mathrm{~min}$. The products were extracted with one volume of 1:1 phenol/chloroform. The DNA was precipitated from the aqueous layer by the addition of 0.1 volume of $3 \mathrm{M}$ sodium acetate and 2.5 volumes of ethanol. After $30 \mathrm{~min}$ of incubation at $-20^{\circ} \mathrm{C}$ and centrifugation at $12000 \mathrm{~g}$ for $30 \mathrm{~min}$ at $4^{\circ} \mathrm{C}$, the pellet was washed with $0.2 \mathrm{~mL}$ of $80 \%$ ethanol and dried in a vacuum centrifuge. DNA was finally linearized by SspI before electrophoresis on a 1\% agarose gel. Resulting gel was stained by EtBr. The experiments were made in quadruplicate.

\subsection{Sensitization of cancer cells by steroid hormones to platinum complexes by clonogenic} assay

MCF-7 cells were seeded on $6 \mathrm{~cm}$ Petri dishes at a density of 400 cells per dish. After 24 hr, a fresh stock solution containing steroid hormone(s), estradiol or estradiol plus progesterone, was prepared in $N, N$-dimethylformamide and added to the dishes so that a final concentration of each hormone was $0.2 \mu \mathrm{M}$. Control dishes were treated with the same volume of $N, N$-dimethylformamide without hormone. The hormone was added at the same time as platinum complex $(\mathbf{1}, \mathbf{2}$, or cisplatin). After $4 \mathrm{hr}$ treatment, the cells were washed with PBS, and fresh medium was added. After 10 days, the cell colonies were stained with $1 \%$ methylene blue and were then counted. Each point is an average of six independent determinations. 


\subsection{Other physical methods}

Absorption spectra were measured with a Beckmann DU-7400 spectrophotometer. FAAS measurements were carried out with a Varian AA240Z Zeeman atomic absorption spectrometer equipped with a GTA 120 graphite tube atomizer. For FAAS analysis DNA was precipitated with ethanol and dissolved in $0.1 \mathrm{M} \mathrm{HCl}$. The gels were visualized by using the BAS 2500 FUJIFILM bioimaging analyzer, and the radioactivities associated with bands were quantitated with the AIDA image analyzer software (Raytest, Germany).

\section{Results}

\subsection{Cytotoxicity}

The cytotoxic activity of the $\mathbf{1}$ and $\mathbf{2}$ tested in the present work was determined against A2780 (parent cisplatin sensitive) and A2780cisR (with acquired cisplatin resistance) human ovarian carcinoma cell lines, commonly used to test cytotoxic activity of cisplatin analogues and other antitumor metallodrugs. The tumor cell lines were incubated for $72 \mathrm{hr}$ with the platinum compounds and the cell survival in the culture treated with the platinum compounds was evaluated as described in the section Experimental Procedures. Results (Table 1) show that the cytotoxicity of $\mathbf{1}$ in cisplatin sensitive A2780 cells was comparable to the cytotoxicity of cisplatin, whereas $\mathbf{2}$ was slightly less cytotoxic. Importantly, both $\mathbf{1}$ and $\mathbf{2}$ were markedly more active in the cisplatin-resistant line A2780cisR and again 2 was less cytotoxic (Table 1). 


\subsection{Repair DNA synthesis by human cell extracts}

To investigate "downstream" effects of DNA damage by adducts of $\mathbf{1}$ and $\mathbf{2}$, we used in vitro systems to study repair of platinum lesions by CFE. DNA repair efficiency in pUC19 plasmid (2686 bp) globally modified by $\mathbf{1 , 2}$ or cisplatin (for comparative purposes) at $\mathrm{r}_{\mathrm{b}}=$ $0.03\left(\mathrm{r}_{\mathrm{b}}\right.$ is defined as the number of molecules of the platinum complex bound per nucleotide residue) was tested using CFE of repair proficient HeLa cells. Repair activity was monitored by measurement of the amount of incorporated radiolabelled nucleotide. The incorporation of radioactive material was corrected for the relative DNA content in each band. As illustrated in Fig. 2, damage-induced DNA repair synthesis detected in the plasmid modified by $\mathbf{1}$ or $\mathbf{2}$ was approximately 38 or $36 \%$, respectively, of that found for the cisplatin at the same level of modification.

\subsection{DNA modification in a cell-free medium}

The cellular DNA repair response strongly depends on the character and extent of DNA damage. Therefore, it was of great interest to characterize DNA distortions induced by $\mathbf{1}$ and 2. With the view of this we examined the DNA binding properties of these complexes and compared them with those of cisplatin. The experiments were aimed at quantification of the binding of $\mathbf{1}$ and $\mathbf{2}$ to mammalian DNA, determination of their preferential binding sites, and characterization of DNA lesions induced by $\mathbf{1}$ and $\mathbf{2}$ within natural DNA. The results of these experiments are described in detail in the Supplemental Information and are summarized in the following paragraph. 


\subsubsection{DNA binding}

CT DNA was incubated with the platinum complexes at $r_{i}$ values of $0.01,0.03,0.05$, and $0.1)\left(r_{i}\right.$ is defined as the molar ratio of free platinum complex to nucleotides at the onset of incubation with DNA) in $10 \mathrm{mM} \mathrm{NaClO}_{4}$ at $37^{\circ} \mathrm{C}$ for 24 or $48 \mathrm{hr}$. The amount of the platinum compound bound to DNA increased with time. In this binding reaction the time at which the binding reached $50 \%\left(\mathrm{t}_{50 \%}\right)$ was $14.9 \pm 0.6 \mathrm{~min}$ and $39 \pm 6 \min$ for $\mathbf{1}$ and $\mathbf{2}$, respectively, and both complexes were quantitatively bound after $24 \mathrm{hr}$. This result indicates that the rate of binding of both $\mathbf{1}$ and $\mathbf{2}$ to natural double-helical DNA is higher than that of cisplatin $\left(\mathrm{t}_{50 \%}=\right.$ ca. 120 min [37]), although cisplatin is also quantitatively bound to DNA after $24 \mathrm{hr}$ under identical experimental conditions [37].

\subsubsection{Transcription mapping of platinum-DNA adducts}

In vitro RNA synthesis by T7 and SP6 RNA polymerases on DNA templates containing adducts of 1 or $\mathbf{2}$ revealed (Fig. S1) that the major stop sites produced by these complexes were at guanine residues, a few stop sites were also at adenine and cytosine residues. These results also suggest that the adducts formed by $\mathbf{1}$ and $\mathbf{2}$ are able to inhibit RNA polymerase.

\subsubsection{Interstrand cross-linking}

We quantitated the interstrand cross-linking efficiency of $\mathbf{1}$ and $\mathbf{2}$ in linearized pUC19 plasmid (Fig. S2). The interstrand cross-linking efficiencies (defined as the number of interstrand crosslinks per one adduct of the platinum complex [17]) of both 1 and 2 (48 $\pm 4 \%$ and $20 \pm 2 \%$, respectively) were significantly higher than that of cisplatin (6\% [38]).

\subsubsection{Characterization of DNA adducts by ethidium bromide fluorescence}


The results of these experiments (Fig. S3) suggest that the conformational distortion induced in DNA by the adducts of $\mathbf{1}$ is more delocalized and extends over more base pairs around the platination sites than in the case of the adducts of $\mathbf{2}$ or mononuclear cisplatin. Thus, these results are consistent with the formation of long-range intra- or interstrand CLs of 1, whereas 2 apparently forms in DNA much less long-range lesions. In aggregate, characterization of DNA adducts of $\mathbf{1}$ and $\mathbf{2}$ by EtBr fluorescence supports the view that the DNA binding modes of these dinuclear platinum compounds are distinctly different.

\subsubsection{Unwinding of negatively supercoiled DNA}

Electrophoresis in native agarose gel was used to quantify the unwinding induced in pUC19 plasmid by adducts of $\mathbf{1}$ and $\mathbf{2}$ by monitoring the degree of supercoiling (Fig. S4). We determined the DNA unwinding angle of $17^{\circ}$ for the adduct of $\mathbf{1}$ and $12^{\circ}$ for that of $\mathbf{2}$. The high level of unwinding induced by $\mathbf{1}$ and $\mathbf{2}$ is notable. Interestingly, the unwinding angle produced by $\mathbf{1}$ is higher than that produced by $\mathbf{2}$. One plausible explanation for this observation might be consistent with a possibility that the additional contribution to unwinding is associated with the interaction of the linker chain of $\mathbf{1}$ with the duplex upon covalent binding of platinum units. Thus, the results of unwinding experiments represent another support for the view that structure of DNA lesions formed by $\mathbf{1}$ is substantially different from the structure of DNA adducts of its counterpart 2.

\subsection{Recognition of DNA adducts by high-mobility-group (HMG)-domain proteins}

The altered structures induced in DNA by cisplatin and its analogs attract HMG-domain and other proteins [30,39]. This binding of HMG-domain proteins to DNA modified by cisplatin and its analogs has been postulated to mediate the antitumor properties of these 
drugs.[39] As dinuclear platinum complexes $\mathbf{1}$ and $\mathbf{2}$ exhibit antitumor activity qualitatively different from cisplatin, it was of interest to examine whether also the adducts formed within DNA by $\mathbf{1}$ or $\mathbf{2}$ are able to be specifically recognized by HMG domain proteins.

To assess the ability of HMGB1 protein to recognize DNA modified by complexes $\mathbf{1}$ and 2 we employed the system of DNA immobilized on streptavidine coated magnetic beads suspended in HMG binding buffer containing HMGB1 protein. $10 \mu \mathrm{g}$ of DNA fragment was immobilized on $1 \mathrm{mg}$ of Dynabeads. Radioactively labeled DNA enabled us to ensure the same quantity of DNA in various samples. First we determined whether HMGB1 protein exhibits the ability to recognize DNA modified by the two new dinuclear compounds. Immobilized DNA (nonmodified or modified by cisplatin, complex $\mathbf{1}$ and $\mathbf{2}$ to $\mathrm{r}_{\mathrm{b}}=0.02$ ) was incubated with HMGB1 protein on ice for $1 \mathrm{hr}$ in the presence of poly(dI-dC) as a competitor. Following the incubation, DNA was washed extensively and bound protein was released in $0.04 \%$ SDS and electrophoresed on $15 \%$ SDS-PAGE.

The HMGB1 protein was found to bind DNA modified by cisplatin, in agreement with experiments published earlier $[40,41]$ that was evidenced by the presence of band migrating near the $34 \mathrm{kDa}$ marker corresponding to HMGB1 protein (Fig. 3A, lane cisPt, Table S1). Interestingly, the band corresponding to HMGB1 was also clearly seen for the probe modified by 1 (Fig. 3A, lane 1); the intensity of this band was almost comparable (80\%) to that found for cisplatin (Table S1). On the other hand, much less effective binding of the HMGB1 to the DNA containing the adducts of $\mathbf{2}$ was detected, the amount of HMGB1 protein bound to this probe was only $15 \%$ of the amount of HMGB1 bound to DNA modified by cisplatin under the same conditions (Fig. 3A, lane 2, Table S1). No binding of the proteins occurred under identical experimental conditions if the same DNA probe was unplatinated (Fig. 3A, lane NoPt). These results clearly showed that DNA modified by $\mathbf{1}$ is efficiently recognized by HMGB1 with relatively high affinity, though slightly less than to the probe containing the 
adducts of cisplatin. In contrast, DNA adducts of $\mathbf{2}$ are recognized by this protein markedly less.

To determine which of the two HMGB1 domains A or B predominates in recognition and binding of DNA lesions of $\mathbf{1}$, the binding of HMGB1 domain A and HMGB1 domain B to the DNA modified by complexes 1 or 2 was investigated (Fig. 3 B,C). The experiments revealed that in agreement with previously published data [41], HMGB1a effectively bound to the probe containing adducts of cisplatin (Fig. 3B, lane cisPt). Considerably weaker binding of HMGB1a was noticed to the probes containing adducts of $\mathbf{1}$ or $\mathbf{2}$; relative amount of HMGB1a protein bound to DNA probe containing adducts of cisplatin, 1 or 2 was $100 \%$, $20 \%$, or $14 \%$, respectively (Fig. 3B, Table S1). On the other hand, the amount of HMGB1b bound to the DNA modified by 1 was two-fold higher compared to that bound to DNA modified by cisplatin (Fig. 3C, Table S1). These results clearly show that DNA damaged by complex 1 was recognized by HMGB1 protein, but in contrast to DNA globally modified by cisplatin, the full-length HMGB1 protein binds to DNA globally modified by 1 mainly through domain B.

Complex 1 modifies DNA so that it forms approximately equal amounts of interstrand and intrastrand adducts (see paragraph Interstrand cross-linking in this Section and Fig. S2). To distinguish which type of lesions formed by $\mathbf{1}$ within DNA is preferentially recognized by HMGB1 protein, the following experiment was performed. The $92 \mathrm{bp}$ fragment of DNA was modified by 1 so that the fragment contained only one adduct per DNA fragment on average. After the modification, DNA was loaded into the denaturating agarose gel and two DNA fractions were purified from the gel, one contained only intrastrand adducts (no interstrand CLs) (F-IAA) and the other contained at least one interstrand CL (F-IEC). These two separated DNA fractions were then allowed to interact with HMGB1b, as described in section Experimental procedures. The amount of HMGB1b protein bound to each DNA fraction was 
determined by SDS/PAGE electrophoresis. The inspection of the electrophoreogram (Fig. 4) revealed that HMGB1b bound to DNA containing interstrand CLs of 1 whereas it bound considerably less (4-fold) to DNA modified by $\mathbf{1}$ to the similar level but containing other adducts, but not interstrand CLs (Table S2).

\subsection{Steroid hormones sensitize cancer cells to complex 1 , but not to complex 2}

Previous studies have shown that HMGB1 protein sensitizes cells to cisplatin by shielding its DNA adducts from nucleotide excision repair [25, 42]. Human breast cancer cells MCF-7 contain estrogen and progesterone receptors and respond to these steroids upregulating HMGB1 protein [43]. Importantly, treatment of these cancer cells with estrogen or progesterone significantly increases the potency of cisplatin apparently owing to the overexpression of HMGB1 [44]. Since DNA adducts of 1 are recognized by HMGB1 protein markedly more than those of 2 (Fig. 3), it was of interest to assess the involvement of HMGdomain proteins in mediating cytotoxicity of the dinuclear $\mathrm{Pt}^{\mathrm{II}}$ complexes tested in the present work. Therefore, we investigated the effects of elevated HMGB1 levels due to steroid hormone treatment in MCF-7 cells on the sensitivity of these cells to 1 or 2 (Fig. 5) using clonogenic assay in the same way as described previously for cisplatin and carboplatin [44]. As anticipated, we found that elevated HMGB1 expression levels were paralleled by increased sensitivity toward 1, but markedly less toward 2 (Fig. 5 and Table S4). For instance, in MCF-7 cells, estradiol or estradiol plus progesterone treatment increased sensitivity toward 1 about 2.7- or 4.2-fold, respectively, when only 50\% of the cells are viable (Fig. 5A); estradiol or estradiol plus progesterone treatment also increased sensitivity toward cisplatin, but only about 1.8 - or 2.5-fold, respectively (Fig. 5C). Thus, sensitivity toward 1 was enhanced due to steroid hormone treatment even considerably more than toward cisplatin. 
Sensitivity of MCF-7 cells, treated with hormones, toward 1, 2, and cisplatin was also clonogenic assay was used, although $\mathrm{IC}_{50}$ data obtained by MTT assay were uniformly higher than in clonogenic assay.

\section{Discussion}

We demonstrate in the present work that the dinuclear complexes $\mathbf{1}$ and $\mathbf{2}$ are quite toxic to the ovarian tumor cells, with $\mathrm{IC}_{50}$ values that were comparable to that observed for cisplatin in the cisplatin sensitive cell line A2780, and noticeably much lower in the cisplatin-resistant line A2780cisR (Table 1). Thus, these results complement those obtained in the previous study [27] showing that complexes $\mathbf{1}$ and $\mathbf{2}$ exhibit the promising cytotoxicity to the human nonsmall-cell lung cancer cell line (A549). Interestingly, the cytotoxicity of both $\mathbf{1}$ and $\mathbf{2}$ to the ovarian tumor cells is characterized by remarkably low resistance factors, equal to or even less than 1, which indicates that the dinuclear platinum complexes examined in the present work are capable of circumventing of cisplatin resistance in some types of the cisplatinresistant lines. In aggregate, no cross-resistance to cisplatin and high cytotoxic effects in cisplatin resistant cells represent important pharmacological features of $\mathbf{1}$ and $\mathbf{2}$.

An important feature of the mechanism underlying antitumor effects of DNA-binding metal-based compounds is repair of their DNA adducts [40, 45]. A persistence of these DNA adducts may potentiate their antitumor effects in the cells sensitive to these compounds $[8,39$, 40]. DNA repair synthesis was investigated in the present work using the CFE from human tumor cells and DNA substrates randomly modified by $\mathbf{1}$ or $\mathbf{2}$. Importantly, the adducts of both 1 and $\mathbf{2}$ induced a considerably lower level of repair synthesis than the adducts of 
cisplatin suggesting a less efficient removal from DNA and enhanced persistence of the adducts of the dinuclear complexes $\mathbf{1}$ and $\mathbf{2}$. Thus, enhanced resistivity of DNA adducts of $\mathbf{1}$ and $\mathbf{2}$ against repair processes appears to be an important factor contributing to ability of $\mathbf{1}$ and $\mathbf{2}$ to overcome resistance towards cisplatin.

Structural features of DNA distortions are considered to be major factors playing a key role in recognition by damaged-DNA recognition-proteins and DNA repair systems. The analysis of DNA binding of $\mathbf{1}$ and $\mathbf{2}$ described in this report and summarized in Table 2 provides experimental support for the view that the binding of these dinuclear platinum complexes modifies DNA in a way which is in several aspects considerably different from modification of DNA by "conventional" mononuclear cisplatin. These differences may suggest that in comparison with adducts of cisplatin the reduced repair of DNA adducts of the dinuclear $\mathrm{Pt}^{\mathrm{II}}$ complexes is a consequence of their different DNA binding mode.

The binding of $\mathbf{1}$ and $\mathbf{2}$ to DNA is considerably faster than the binding of dichloro derivatives of mononuclear $\mathrm{Pt}^{\mathrm{II}}$ complexes, such as cisplatin or transplatin ( $\mathrm{t}_{50 \%} \sim 120 \mathrm{~min}$ [37]) likely reflecting the higher charge. In addition, the different rate of the binding of $\mathbf{1}$ and 2 may be associated with the differences in the linking chains, such as flexibility and hydrophobicity, which may affect pre-association step of DNA binding [46, 47].

Importantly, the effect of the linker character and geometry results in enhanced extent of the long-range delocalized cross-linking by $\mathbf{1}$ as revealed by fluorescence measurements with EtBr (Fig. S3). Similarly, DNA interstrand cross-linking by 1 is enhanced compared with that by 2 (Fig. S2, Table 2). This enhanced interstrand crosslinking efficiency of 1 correlates with its higher potency compared with that of $\mathbf{2}$ so that interstrand CLs appear to play the prevalent role in cytotoxicity of $\mathbf{1}$. In addition, compared with $\mathbf{2 ,} \mathbf{1}$ distorts DNA secondary structure differently and unwinds DNA more (Fig. S4 and Table 2). Thus, it is reasonable to expect that several "downstream" intracellular effects of DNA adducts of $\mathbf{1}$ and $\mathbf{2}$ are different. 
Consistent with this view is the observation that affinity of HMG-domain proteins to DNA adducts of $\mathbf{1}$ is markedly higher than that to DNA adducts of $\mathbf{2}$ (Fig. 3A). The fulllength HMGB1 protein consists of two tandem HMG box domains (A and B) and a Cterminal acidic tail. Both A and B domains of HMGB1 protein share a common HMG box structure. Domain A has a higher binding affinity to distorted DNA than domain B, whereas domain B bends DNA more effectively [48]. Because of the importance of the HMG box interaction with DNA [25], the studies of the individual HMG domains and their DNA complexes are of great interest. It has been shown that full-length HMGB1 protein binds to DNA containing a site-specific 1,2-GG intrastrand CL of cisplatin mainly through domain A, whereas domain B alone binds cisplatinated DNA much more weakly than domain A alone [41]. In contrast to these data, binding of full-length HMGB1 to DNA modified by the dinuclear complex $\mathbf{1}$ is mediated preferentially by domain B (Fig. 3B, C). This result, in combination with our previous findings that the domain B of the HMGB1 protein with the A/B linker plays a crucial role in the interaction between full-length HMGB1 protein and DNA interstrand cross-linked by cisplatin [30], implies a possible role of the interstrand DNA adducts of $\mathbf{1}$ in the interaction with HMG-domain proteins. Therefore, we tested the contribution of DNA intrastrand and interstrand adducts formed by 1 to the binding of HMGB1 to DNA globally modified by $\mathbf{1}$. The sample containing DNA fragment globally modified by 1 was divided into two DNA fractions, one containing only intrastrand adducts (no interstrand CLs) and the other containing interstrand CLs and the affinity of HMGB1b towards these two fractions was tested. The results unambiguously show the prevalent role of DNA interstrand CLs of $\mathbf{1}$ in recognition and binding of DNA modified by $\mathbf{1}$ to full-length HMGB1 protein. To our knowledge, this is the first evidence for strong specific recognition and binding of HMG-domain proteins to DNA modified by a polynuclear platinum complex. Previously, a weak recognition of DNA interstrand CLs of $\left[\left\{\right.\right.$ trans- $\left.\mathrm{PtCl}\left(\mathrm{NH}_{3}\right)_{2}\right\} \mathrm{H}_{2} \mathrm{~N}\left(\mathrm{CH}_{2}\right)_{2}$ - 
$\left.{ }_{6} \mathrm{NH}_{2}\right] \mathrm{Cl}_{2}$ complexes by full-length HMGB1 protein has only been reported [7], whereas a recognition of intrastrand CLs of these complexes has not been detected.

The results of the present work provide evidence that HMGB1 domain B controls a relatively strong binding of full-length HMGB1 to DNA modified by 1 when both domain A and $\mathrm{B}$ are present. It is quite conceivable that domain B is the dominating domain in HMGB1 protein that binds to the interstrand $\mathrm{CL}$ of $\mathbf{1}$, while domain A only facilitates binding by providing additional protein-DNA interactions. A structure of full-length HMGB1 complexed with DNA containing interstrand CL of 1 will provide more insights into how HMG-domain proteins can mediate cytotoxicity of $\mathbf{1}$. On the other hand, the affinities of full-length HMGB1 protein and its domain A to DNA modified by $\mathbf{2}$ are relatively weak and almost identical. This result is consistent with the view and supports the hypothesis that the binding of full-length HMGB1 protein to DNA modified by the dinuclear complex 2, although relatively weak, is mediated preferentially by the domain A. Collectively, the results of this work demonstrate that not only DNA binding modes of $\mathbf{1}$ and $\mathbf{2}$ and resulting conformational alterations are noticeably different, but also "downstream" intracellular effects of DNA adducts of the two dinuclear complexes may be different, particularly in the cells in which the HMGB1 level is high and in which HMGB1 protein is not prevented from interacting with platinum-modified DNA.

It has been shown that specific interaction between adducts of "conventional" cisplatin and cellular HMG-domain proteins modulate the sensitivity of tumor cells to this drug. In particular, protein-DNA interactions induced by cisplatin inhibit replication,[49] shield the adducts from nucleotide excision repair [50] and interfere with transcription by recruiting transcription factors from their native binding sites [51, 52]. Therefore, it is reasonable to assume that such interactions may also differently modulate the cellular responses both to the 
platinum dinuclear complexes $\mathbf{1}$ and $\mathbf{2}$ and also to the class of dinuclear complexes tested in the present work and cisplatin.

In conclusion, the results of the present work are consistent with the hypothesis that the unique properties of interstrand CLs of the class of bifunctional polynuclear platinum complexes tested in the present work and resulting conformational alterations in DNA have critical consequences for their antitumor effects. An interesting finding that might be also translated to the clinical trials is that treatment leading to enhancement of level of HMGdomain proteins in tumor cells should allow the regimens involving $\mathbf{1}$ to show increased antitumor effects toward these cells.

\section{Acknowledgements}

This research was supported by the Ministry of Education of the CR (MSMT LC06030, 6198959216, ME08017, ME10066, OC08003, and OC09018), the Academy of Sciences of the Czech Republic (Grants KAN200200651, M200040901, AV0Z50040507, and AV0Z50040702), the Grant Agency of the Academy of Sciences of the CR (IAA400040803), and the Grant Agency of the CR (301/09/H004 and P301/10/0598). Financial support from the National Natural Science Foundation of China (No. 90713001) is also acknowledged. J.K. is an international research scholar of the Howard Hughes Medical Institute. The authors also acknowledge that their participation in the EU COST Action D39 has enabled them to exchange regularly their most recent ideas in the field of anticancer metallodrugs with several European colleagues.

\section{Appendix A. Supplementary data}

Supplementary data associated with this article can be found, in the online version, at doi: ... 


\section{References}

[1] Pratesi G, Perego P, Polizzi D, Righetti SC, Supino R, Caserini C, et al. A novel charged trinuclear platinum complex effective against cisplatin-resistant tumours: hypersensitivity of p53-mutant human tumour xenografts. Br J Cancer 1999;80:1912-9.

[2] Farrell N. Polynuclear platinum drugs. In: Sigel A, Sigel H, editors. Metal ions in biological systems. New York, Basel: Marcel Dekker, Inc.; 2004, p. 251-96.

[3] Brabec V, Kasparkova J. Modifications of DNA by platinum complexes: Relation to resistance of tumors to platinum antitumor drugs. Drug Resist Updat 2005;8:131-46.

[4] Brabec V, Kasparkova J. DNA interactions of platinum anticancer drugs. Recent advances and mechanisms of action. In: Perez-Martin J-M, Fuertes MA, Alonso C, editors. Metal compounds in cancer chemotherapy. Trivandrum, Kerala (India): Research Signpost; 2005, p. 187-218.

[5] Brabec V, Christofis P, Slamova M, Kostrhunova H, Novakova O, Najajreh Y, et al. DNA interactions of new cytotoxic tetrafunctional dinuclear platinum complex trans,trans-[ $\left\{\mathrm{PtCl}_{2}\left(\mathrm{NH}_{3}\right)\right\}_{2}$ (piperazine)]. Biochem Pharmacol 2007;73:1887-900.

[6] Cossa G, Gatti L, Zunino F, Perego P. Strategies to improve the efficacy of platinum compounds. Curr Med Chem 2009;16:2355-65.

[7] Kasparkova J, Farrell N, Brabec V. Sequence specificity, conformation, and recognition by HMG1 protein of major DNA interstrand cross-links of antitumor dinuclear platinum complexes. J Biol Chem 2000;275:15789-98.

[8] Kasparkova J, Zehnulova J, Farrell N, Brabec V. DNA interstrand cross-links of the novel antitumor trinuclear platinum complex BBR3464. Conformation, recognition by 
high mobility group domain proteins, and nucleotide excision repair. J Biol Chem 2002;277:48076-86.

[9] Brabec V, Kasparkova J, Vrana O, Novakova O, Cox JW, Qu Y, et al. DNA modifications by a novel bifunctional trinuclear platinum Phase I anticancer agent. Biochemistry 1999;38:6781-90.

[10] Kasparkova J, Novakova O, Vrana O, Farrell N, Brabec V. Effect of geometric isomerism in dinuclear platinum antitumor complexes on DNA interstrand crosslinking. Biochemistry 1999;38:10997-1005.

[11] Zehnulova J, Kasparkova J, Farrell N, Brabec V. Conformation, recognition by high mobility group domain proteins, and nucleotide excision repair of DNA intrastrand cross-links of novel antitumor trinuclear platinum complex BBR3464. J Biol Chem 2001;276:22191-9.

[12] Roberts JD, Peroutka J, Farrell N. Cellular pharmacology of polynuclear platinum anticancer agents. J Inorg Biochem 1999;77:51-7.

[13] Roberts JD, Beggiolin G, Manzotti C, Piazzoni L, Farrell N. Comparison of cytotoxicity and cellular accumulation of polynuclear platinum complexes in L1210 murine leukemia cell lines. J Inorg Biochem 1999;77:47-50.

[14] Servidei T, Ferlini C, Riccardi A, Meco D, Scambia G, Segni G, et al. The novel trinuclear platinum complex BBR3464 induces a cellular response different from cisplatin. Eur J Cancer 2001;37:930-8.

[15] Farrell N. Polynuclear charged platinum compounds as a new class of anticancer agents: Toward a new paradigm. In: Kelland LR, Farrell NP, editors. Platinum-based drugs in cancer therapy. Totowa/NJ: Humana Press Inc.; 2000, p. 321-38.

[16] Harris AL, Yang X, Hegmans A, Povirk L, Ryan JJ, Kelland L, et al. Synthesis, characterization, and cytotoxicity of a novel highly charged trinuclear platinum 
compound. Enhancement of cellular uptake with charge. Inorg Chem 2005;44:9598600.

[17] Farrell N, Qu Y, Feng L, Van Houten B. Comparison of chemical reactivity, cytotoxicity, interstrand cross-linking and DNA sequence specificity of bis(platinum) complexes containing monodentate or bidentate coordination spheres with their monomeric analogues. Biochemistry 1990;29:9522-31.

[18] Summa N, Maigut J, Puchta R, van Eldik R. Possible biotransformation reactions of polynuclear Pt(II) complexes. Inorg Chem 2007;46:2094-104.

[19] Oehlsen ME, Qu Y, Farrell N. Reaction of polynuclear platinum antitumor compounds with reduced glutathione studied by multinuclear $\left({ }^{1} \mathrm{H},{ }^{1} \mathrm{H}-{ }^{15} \mathrm{~N}\right.$ gradient heteronuclear single-quantum coherence, and ${ }^{195} \mathrm{Pt}$ ) NMR spectroscopy. Inorg Chem 2003;42:5498 506.

[20] Billecke C, Finniss S, Tahash L, Miller C, Mikkelsen T, Farrell NP, et al. Polynuclear platinum anticancer drugs are more potent than cisplatin and induce cell cycle arrest in glioma. Neuro Oncol 2006;8:215-26.

[21] Mitchell C, Kabolizadeh P, Ryan J, Roberts JD, Yacoub A, Curiel DT, et al. Low-dose BBR3610 toxicity in colon cancer cells is p53-independent and enhanced by inhibition of epidermal growth factor receptor (ERBB1)-Phosphatidyl inositol 3 kinase signaling Mol Pharmacol 2007;72:704-14.

[22] Williams JW, Qu Y, Bulluss GH, Alvorado E, Farrell NP. Dinuclear platinum complexes with biological relevance based on the 1,2-diaminocyclohexane carrier ligand. Inorg Chem 2007;46:5820-2.

[23] Fan D, Yang X, Wang X, Zhang S, Mao J, Ding J, et al. A dinuclear monofunctional platinum(II) complex with an aromatic linker shows low reactivity towards glutathione 
but high DNA binding ability and antitumor activity. J Biol Inorg Chem 2007;12:65565.

[24] Jamieson ER, Lippard SJ. Structure, recognition, and processing of cisplatin-DNA adducts. Chem Rev 1999;99:2467-98.

[25] Jung Y, Lippard SJ. Direct cellular responses to platinum-induced DNA damage. Chem Rev 2007;107:1387-407.

[26] Brabec V, Kasparkova J. Role of DNA repair in antitumor effects of platinum drugs. In: Hadjiliadis N, Sletten E, editors. Metal complex - DNA interactions. Chichester, UK: Wiley; 2009, p. 175-208.

[27] Zhu J, Lin M, Fan D, Wu Z, Zhang J, Luc Y, et al. The role of bridging ligands in determining DNA-binding ability and cross-linking patterns of dinuclear platinum(II) antitumor complexes. Dalton Trans 2009:10889 -95.

[28] Brabec V, Palecek E. The influence of salts and $\mathrm{pH}$ on polarographic currents produced by denatured DNA. Biophysik 1970;6:290-300.

[29] Brabec V, Palecek E. Interaction of nucleic acids with electrically charged surfaces. II. Conformational changes in double-helical polynucleotides. Biophys Chem 1976;4:7692.

[30] Kasparkova J, Delalande O, Stros M, Elizondo-Riojas MA, Vojtiskova M, Kozelka J, et al. Recognition of DNA interstrand cross-link of antitumor cisplatin by HMGB1 protein. Biochemistry 2003;42:1234-44.

[31] Stros M. DNA bending by the chromosomal protein HMG1 and its high mobility group box domains. Effect of flanking sequences. J Biol Chem 1998;273:10355-61.

[32] Stros M. Two mutations of basic residues within the N-terminus of HMG-1 B domain with different effects on DNA supercoiling and binding to bent DNA. Biochemistry 2001;40:4769-79. 
[33] Reardon JT, Vaisman A, Chaney SG, Sancar A. Efficient nucleotide excision repair of cisplatin, oxaliplatin, and bis-aceto-ammine-dichloro-cyclohexylamine-platinum(IV) (JM216) platinum intrastrand DNA diadducts. Cancer Res 1999;59:3968-71.

[34] Manley JL, Fire A, Cano A, Sharp PA, Gefter ML. DNA-dependent transcription of adenovirus genes in a soluble whole-cell extract. Proc Natl Acad Sci USA $1980 ; 77: 3855-9$.

[35] Alley MC, Scudiero DA, Monks A, Hursey ML, Czerwinski MJ, Fine DL, et al. Feasibility of drug screening with panels of human tumor cell lines using a microculture tetrazolium assay. Cancer Res 1988;48:589-601.

[36] Kim SD, Vrana O, Kleinwächter V, Niki K, Brabec V. Polarographic determination of subnanogram quantities of free platinum in reaction mixture with DNA. Anal Lett 1990;23:1505-18.

[37] Bancroft DP, Lepre CA, Lippard SJ. ${ }^{195} \mathrm{Pt}$ NMR kinetic and mechanistic studies of cisdiamminedichloroplatinum and trans-diamminedichloroplatinum(II) binding to DNA. J Am Chem Soc 1990;112:6860-71.

[38] Brabec V, Leng M. DNA interstrand cross-links of trans-diamminedichloroplatinum(II) are preferentially formed between guanine and complementary cytosine residues. Proc Natl Acad Sci USA 1993;90:5345-9.

[39] Brabec V. DNA modifications by antitumor platinum and ruthenium compounds: their recognition and repair. Prog Nucleic Acid Res Mol Biol 2002;71:1-68.

[40] Cohen SM, Lippard SJ. Cisplatin: From DNA damage to cancer chemotherapy. Prog Nucleic Acid Res Mol Biol 2001;67:93-130.

[41] Jung YW, Lippard SJ. Nature of full-length HMGB1 binding to cisplatin-modified DNA. Biochemistry 2003;42:2664-71. 
[42] Huang JC, Zamble DB, Reardon JT, Lippard SJ, Sancar A. HMG-domain proteins specifically inhibit the repair of the major DNA adduct of the anticancer drug cisplatin by human excision nuclease. Proc Natl Acad Sci USA 1994;91:10394-8.

[43] Chau KY, Lam HYP, Lee KLD. Estrogen treatment induces elevated expression of HMG1 in MCF-7 cells. Exp Cell Res 1998;241:269-72.

[44] He Q, Liang CH, Lippard SJ. Steroid hormones induce HMG1 overexpression and sensitize breast cancer cells to cisplatin and carboplatin. Proc Natl Acad Sci USA 2000;97:5768-72.

[45] Brabec V, Kasparkova J. Molecular aspects of resistance to antitumor platinum drugs. Drug Resist Updat 2002;5:147-61.

[46] Hegmans A, Berners-Price SJ, Davies MS, Thomas D, Humphreys A, Farrell N. Long range 1,4 and 1,6-interstrand cross-links formed by a trinuclear platinum complex. Minor groove pre-association affects kinetics and mechanism of cross-link formation as well as adduct structure. J Am Chem Soc 2004;126:2166-80.

[47] Berners-Price SJ, Davies MS, Cox JW, Thomas DS, Farrell N. Competitive reactions of interstrand and intrastrand DNA-Pt adducts: A dinuclear-platinum complex preferentially forms a 1,4-interstrand cross-link rather than a 1,2 intrastrand cross-link on binding to a GG 14-Mer duplex. Chem Eur J 2003;9:713-25.

[48] Thomas JO. HMG 1 and 2: architectural DNA-binding proteins. Biochem Soc Trans 2001;29:395-401.

[49] Comess KM, Burstyn JN, Essigmann JM, Lippard SJ. Replication inhibition and translesion synthesis on templates containing site-specifically placed cisdiamminedichloroplatinum(II) DNA adducts. Biochemistry 1992;31:3975-90.

[50] Zamble DB, Mu D, Reardon JT, Sancar A, Lippard SJ. Repair of cisplatin-DNA adducts by the mammalian excision nuclease. Biochemistry 1996;35:10004-13. 
[51] Zhai XQ, Beckmann H, Jantzen HM, Essigmann JM. Cisplatin-DNA adducts inhibit ribosomal RNA synthesis by hijacking the transcription factor human upstream binding factor. Biochemistry 1998;37:16307-15.

[52] Vichi P, Coin F, Renaud JP, Vermeulen W, Hoeijmakers JHJ, Moras D, et al. Cisplatinand UV-damaged DNA lure the basal transcription factor TFIID/TBP. EMBO J 1997;16:7444-56.

[53] Fichtinger-Schepman AMJ, Van der Veer JL, Den Hartog JHJ, Lohman PHM, Reedijk J. Adducts of the antitumor drug cis-diamminedichloroplatinum(II) with DNA: Formation, identification, and quantitation. Biochemistry 1985;24:707-13.

[54] Keck MV, Lippard SJ. Unwinding of supercoiled DNA by platinum ethidium and related complexes. J Am Chem Soc 1992;114:3386-90. 
Table 1. In vitro growth inhibition of human ovarian cisplatin sensitive (A2780) and resistant (A2780cisR) cells, $\mathrm{IC}_{50}(\mu \mathrm{M})^{\mathrm{a}, \mathrm{b}}$

\begin{tabular}{lcc}
\hline & A2780 & A2780 cisR $^{\mathrm{c}}$ \\
\hline cisplatin & $2.8 \pm 0.7$ & $18.6 \pm 0.4(6.6)$ \\
$\mathbf{1}$ & $2.7 \pm 0.7$ & $2.7 \pm 0.1(1)$ \\
$\mathbf{2}$ & $4.8 \pm 2.7$ & $3.6 \pm 1.1(0.75)$ \\
\hline
\end{tabular}

${ }^{a}$ Drug-treatment period was $72 \mathrm{hr}$.

${ }^{\mathrm{b}}$ Values shown in the table are the means $( \pm \mathrm{SEM})$ of three separate experiments, each conducted with 6 replicates.

${ }^{\mathrm{c}}$ Resistance factor, defined as $\mathrm{IC}_{50}$ (resistant) / $\mathrm{IC}_{50}$ (sensitive), is given in parentheses. 
Table 2. Summary of the effects of complex $\mathbf{1}, \mathbf{2}$ and cisplatin on DNA ${ }^{\text {a }}$

\begin{tabular}{|c|c|c|c|}
\hline & $\mathbf{1}$ & 2 & cisplatin \\
\hline DNA binding $\left(\mathrm{t}_{50 \%}\right)(\mathrm{min})^{\mathrm{b}}$ & $14.9 \pm 0.6$ & $39 \pm 6$ & $120^{c}$ \\
\hline Preferential DNA binding sites ${ }^{\mathrm{d}}$ & G & G & $\mathrm{GG}, \mathrm{AG}^{\mathrm{e}}$ \\
\hline Reduction of EtBr fluorescence & strong & medium & medium \\
\hline Plasmid DNA unwinding angle/adduct & $17^{\circ}$ & $12^{\circ}$ & 110 \\
\hline$\%$ interstrand cross-links/adduct & $48 \pm 4$ & $20 \pm 2$ & \\
\hline
\end{tabular}

${ }^{a}$ See also Figs. S1 - S4.

${ }^{\mathrm{b}}$ See the text for details.

${ }^{\mathrm{c}}$ Ref. [37].

${ }^{\mathrm{d}}$ Determined by transcription mapping.

${ }^{\mathrm{e}}$ Ref. [53].

${ }^{\mathrm{f}}$ Ref. [54].

${ }^{\mathrm{g}}$ Ref. [38]. 
Figure Captions

Fig. 1 - Structures of the platinum complexes.

Fig. 2 - In vitro DNA repair synthesis assay. Repair synthesis of the extract prepared from the repair-proficient HeLa cell line used as substrates nonmodified pBR322 plasmid and pUC19 plasmid nonmodified or modified at $\mathrm{r}_{\mathrm{b}}=0.03$ by cisplatin, complex $\mathbf{1}$, and complex 2 . (A) Results of a typical experiment. Top panel, a photograph of the EtBr stained gel; bottom panel, autoradiogram of the gel showing incorporation of $\left[\alpha-{ }^{32} \mathrm{P}\right] \mathrm{dCTP}$. Lanes: 1 , nonmodified pBR322 plus pUC19 plasmids; 2, nonmodified pBR322 plus pUC19 modified by cisplatin; 3, nonmodified pBR322 plus pUC19 modified by 1; 4, nonmodified pBR322 plus pUC19 modified by 2. (B) Incorporation of dCTP into nonmodified or platinated pUC19 plasmid. For all quantifications representing mean values of three separate experiments, incorporation of radioactive material is corrected for the relative DNA content in each band. The radioactivity associated with the incorporation of $\left[\alpha-{ }^{32} \mathrm{P}\right] \mathrm{dCTP}$ into DNA modified by cisplatin was taken as $100 \%$. Values shown in the graph are the means $( \pm$ SEM $)$ of three separate experiments, each conducted with 4 replicates.

Fig. 3 - Recognition by HMG-domain proteins of platinated DNA. Affinity of full-length HMGB1 (A) HMGB1 domain A (B), and HMGB1 domain B (C) to nonmodified (control) DNA (lanes noPt) or DNA modified by cisplatin (lanes cisPt), complex 1 (lanes 1) or complex 2 (lanes 2). Lanes M, a protein size marker; lane HMGB1, HMGB1 protein was loaded; lane HMGB1 dom A, HMGB1domain A was loaded. 
Fig. 4 - Recognition by HMGB1 domain B of DNA fragments intrastrand or interstrand crosslinked by complex 1. After reaction with $\mathbf{1}$, the DNA was separated by gel electrophoresis so that the fraction F-IEC contained all interstrand cross-linked fragments and the fraction F-IAA contained exclusively platinum adducts formed within one strand of DNA (contained no interstrand CLs, for other details, see the text). Lanes: M, a protein size marker; noPt, control, nonplatinated; F-IAA, intrastrand adducts containing DNA incubated with HMGB1 domain B; F-IEC, interstrand cross-links containing DNA incubated with HMGB1 domain B.

Fig. 5 - The effects of estradiol or estradiol plus progesterone cotreatment on sensitivity of MCF-7 cells towards complexes 1 (A), 2 (B) or cisplatin (C) determined by clonogenic assay. MCF-7 cells were cotreated with estradiol $(0.2 \mu \mathrm{M})(\boldsymbol{\Delta})$ or estradiol $(0.2 \mu \mathrm{M})$ plus progesterone $(0.2 \mu \mathrm{M})(\boldsymbol{\nabla})$ with platinum complex for $4 \mathrm{hr}$; $(\square)$, no steroid hormone added. Values shown in the graphs are the means $( \pm$ SEM) of six separate experiments, each conducted with 6 replicates; where error bars are not shown, they were smaller than the symbols. 


\section{Mechanistic insights into antitumor effects of new dinuclear cis}

\section{$\mathrm{Pt}^{\mathrm{II}}$ complexes containing aromatic linkers}

Lenka Zerzankova ${ }^{\text {a }, \text { Hana Kostrhunova }}{ }^{\text {a }}$, Marie Vojtiskova ${ }^{\text {a }, ~ O l g a ~ N o v a k o v a ~}{ }^{\text {a }}$,

Tereza Suchankova ${ }^{\mathrm{b}}$, Miaoxin Lin ${ }^{\mathrm{c}}$, Zijian Guo $^{\mathrm{c}}$, Jana Kasparkova ${ }^{\mathrm{a}, *}$

Viktor Brabec ${ }^{\mathrm{a}, *}$

${ }^{a}$ Institute of Biophysics, Academy of Sciences of the Czech Republic, v.v.i., CZ-61265 Brno,

Czech Republic

${ }^{b}$ Department of Experimental Physics, Faculty of Sciences, Palacky University, tr. Svobody

26, 77146 Olomouc, Czech Republic

${ }^{c}$ State Key Laboratory of Coordination Chemistry, School of Chemistry and Chemical Engineering, Nanjing University, Nanjing 210093, PR China

Classification: (1) Antibiotics and Chemotherapeutics

* Corresponding authors at: Institute of Biophysics, Academy of Sciences of the Czech Republic, v.v.i., Kralovopolska 135, CZ-61265 Brno, Czech Republic. Tel.: +420-541517148; fax: $+420-541240499$.

E-mail addresses: jana@ibp.cz (J. Kasparkova); brabec@ibp.cz (V. Brabec) 
Abbreviations: BBR3464, [\{trans-PtCl( $\left.\left(\mathrm{NH}_{3}\right)_{2}\right\}_{2}-\mu-$ trans- $\left.\mathrm{Pt}\left(\mathrm{NH}_{3}\right)_{2}\left(\mathrm{NH}_{2}\left(\mathrm{CH}_{2}\right)_{6} \mathrm{NH}_{2}\right)_{2}\right]^{4+}$; BBR3610, $\left[\left\{\text { trans-PtCl }\left(\mathrm{NH}_{3}\right)_{2}\right\}_{2}-\mu-\left\{\text { trans- }\left(\mathrm{H}_{2} \mathrm{~N}\left(\mathrm{CH}_{2}\right)_{6} \mathrm{NH}_{2}\left(\mathrm{CH}_{2}\right)_{2} \mathrm{NH}_{2}\left(\mathrm{CH}_{2}\right)_{6} \mathrm{NH}_{2}\right\}\right]^{4+} ; \mathrm{bp}\right.$, base pair; cisplatin, cis-diamminedichloroplatinum(II); CFE, cell-free extract; CL, crosslink; complex 1, $\left\{\left[\text { cis-Pt }\left(\mathrm{NH}_{3}\right)_{2} \mathrm{Cl}\right]_{2}\left(4,4^{\prime}-\text { methylenedianiline }\right)\right\}^{2+}$; complex 2, $\{[$ cis$\left.\mathrm{Pt}\left(\mathrm{NH}_{3}\right)_{2} \mathrm{Cl}\right]_{2}\left(\alpha, \alpha^{\prime}\right.$-diamino-p-xylene $\left.)\right\}^{2+} ; \mathrm{CT}$, calf-thymus; DPP, differential pulse polarography; EtBr, ethidium bromide; FAAS, flameless atomic absorption spectrophotometry; $\mathrm{HMG}$, high-mobility-group; $\mathrm{IC}_{50}$, concentration inhibiting cell growth by 50\%; MTT, [3-(4,5-dimethylthiazol-2-yl)-2,5-diphenyltetrazolium bromide]; PAGE, polyacrylamide gel electrophoresis; $r_{\mathrm{b}}$, the number of molecules of the metal complex bound per nucleotide residue; $r_{\mathrm{i}}$, the molar ratio of free metal complex to nucleotide-phosphates at the onset of incubation with DNA; SDS, sodium dodecyl sulfate. 


\section{ABSTRACT}

The primary objective was to understand more deeply the molecular mechanism underlying different antitumor effects of dinuclear $\mathrm{Pt}^{\mathrm{II}}$ complexes containing aromatic linkers of different length, $\left\{\left[\text { cis- } \mathrm{Pt}\left(\mathrm{NH}_{3}\right)_{2} \mathrm{Cl}\right]_{2}\left(4,4^{\prime}-\text { methylenedianiline }\right)\right\}^{2+}(\mathbf{1})$ and $\left\{\left[\text { cis- } \mathrm{Pt}\left(\mathrm{NH}_{3}\right)_{2} \mathrm{Cl}\right]_{2}\left(\alpha, \alpha^{\prime}-\right.\right.$ diamino-p-xylene $)\}^{2+}(2)$. These complexes belong to a new generation of promising polynuclear platinum drugs resistant to decomposition by sulfur nucleophiles which hampers clinical use of bifunctional polynuclear trans $\mathrm{Pt}^{\mathrm{II}}$ complexes hitherto tested. Results obtained with the aid of methods of molecular biophysics and pharmacology reveal differences and new details of DNA modifications by $\mathbf{1}$ and $\mathbf{2}$ and recognition of these modifications by cellular components. The results indicate that the unique properties of DNA interstrand crosslinks of this class of polynuclear platinum complexes and recognition of these cross-links may play a prevalent role in antitumor effects of these metallodrugs. Moreover, the results show for the first time a strong specific recognition and binding of high-mobility-group domain proteins, which are known to modulate antitumor effects of clinically used platinum drugs, to DNA modified by a polynuclear platinum complex.

Key words: dinuclear platinum; antitumor; DNA damage; interstrand cross-link; recognition 


\section{Introduction}

The polynuclear platinum compounds represent a class of new antitumor metallodrugs that is structurally distinct from conventional cis-diamminedichloridoplatinum(II) (cisplatin) and its mononuclear analogues, and whose clinical profile and mechanism of action are different from these established platinum mononuclear compounds [1-6]. DNA adducts of polynuclear platinum complexes, whose formation is associated with antitumor effects of these agents, differ significantly in structure and type from those of mononuclear platinum complexes. Especially because of markedly more distant leaving groups, long-range intra- and interstrand crosslinks (CLs) are formed in DNA which affect DNA conformation, are recognized by specific proteins and repaired differently in comparison with the CLs of cisplatin and its mononuclear analogues [7-11]. Importantly, cells with resistance to cisplatin showed no cross-resistance to polynuclear platinum compounds [12-14]. The polynuclear platinum complexes also exhibit significantly higher levels of cellular uptake very likely because of their lipophilic linker chains and hydrophilic platinum-amine coordination spheres, which may enhance membrane permeability $[13,15,16]$.

The biological activity of polynuclear platinum complexes may be modulated by the geometry and number of leaving groups in the coordination sphere of platinum atoms as well as by the nature of linkers connecting the platinum centers. In contrast with the mononuclear complexes, such as antitumor cisplatin and clinically ineffective transplatin, in the dinuclear case both geometries are antitumor active [2], although DNA adducts (CLs) as well as local conformational distortions on DNA and their recognition by cellular components are affected by geometry $[7,10,17]$. The dinuclear cis isomer $\left[\left\{\text { cis- } \mathrm{PtCl}\left(\mathrm{NH}_{3}\right)_{2}\right\}_{2}\left(\mathrm{H}_{2} \mathrm{~N}-\left(\mathrm{CH}_{2}\right)_{6}-\mathrm{NH}_{2}\right]^{2+}\right.$ is kinetically more inert in its reactions with DNA and in double-stranded DNA produces more interstrand crosslinks than its trans counterpart [10]. 
Also importantly, the general structure, such as $\left[\left\{\text { trans }-\mathrm{PtCl}\left(\mathrm{NH}_{3}\right)_{2}\right\}_{2}-\mu-\mathrm{Y}\right]^{n+}(\mathrm{Y}=$ $\mathrm{NH}_{2}\left(\mathrm{CH}_{2}\right)_{6} \mathrm{NH}_{2}$, spermidine, spermine (BBR3610), trans- $\mathrm{Pt}\left(\mathrm{NH}_{3}\right)_{2}\left(\mathrm{H}_{2} \mathrm{~N}\left(\mathrm{CH}_{2}\right)_{6} \mathrm{NH}_{2}\right)_{2}$ (BBR3464), etc.), is susceptible to decomposition by the sulfur nucleophiles[18] since substitution of the Pt-Cl bond by a trans-influencing S donor results in bridge cleavage [1921]. Hence, the antitumor polynuclear trans $\mathrm{Pt}^{\mathrm{II}}$ complexes, such as for instance trinuclear BBR3464 or dinuclear BR3610, undergo deactivation upon reaction with sulfur nucleophiles, which could result in decreased bioavailability, as well as in increased amounts of toxic metabolites in the host system, which may limit their clinical use [19]. On the other hand, the cis geometry as in $\left[\left\{\text { cis- } \mathrm{PtCl}\left(\mathrm{NH}_{3}\right)_{2}\right\}_{2}-\mu-\mathrm{Y}\right]^{n+}$ should preserve the main features of antitumor polynuclear $\mathrm{Pt}^{\mathrm{II}}$ complexes but with enhanced stability to metabolic deactivation.

In an effort to design a polynuclear platinum compound that maintains the target (DNA) binding profile of the cytotoxic $\mathrm{Pt}^{\mathrm{II}}$ polynuclear compounds and is less susceptible to metabolic decomposition, the long-chain bifunctional dinuclear cis platinum complexes $\left[\{\mathrm{PtCl}(\mathrm{DACH})\}_{2}-\mu-\mathrm{H}_{2} \mathrm{~N}\left(\mathrm{CH}_{2}\right)_{6} \mathrm{NH}_{2}\left(\mathrm{CH}_{2}\right)_{2} \mathrm{NH}_{2}\left(\mathrm{CH}_{2}\right)_{6} \mathrm{NH}_{2}\right]^{4+}(\mathrm{DACH}=1,2-$ diaminocyclohexane) and $\left\{\left[\text { cis- } \mathrm{Pt}\left(\mathrm{NH}_{3}\right)_{2} \mathrm{Cl}\right]_{2}\left(4,4^{\prime}-\text {-methylenedianiline }\right)\right\}^{2+}$ (complex 1, Fig. 1) were synthesized $[22,23]$. Hence, both dinuclear cis $\mathrm{Pt}^{\mathrm{II}}$ complexes exhibit enhanced stability to metabolic deactivation $[22,23]$.

Platinum-DNA binding, recognition of platinated DNA by proteins and DNA repair are important pharmacological features dictating a platinum drug's efficacy [2, 24, 25]. As regards molecular mechanisms of antitumor polynuclear $\mathrm{Pt}^{\mathrm{II}}$ complexes, a great attention has been so far paid mostly to polynuclear trans $\mathrm{Pt}^{\mathrm{II}}$ complexes whose clinical application is limited due to their lowered stability to metabolic deactivation. Thus, the important aim of this study was to broaden theoretical background of biological (antitumor) effects of dinuclear cis $\mathrm{Pt}^{\mathrm{II}}$ complexes, which exhibit enhanced stability to metabolic deactivation. The primary objective in the present study was to understand more deeply those aspects of the molecular 
mechanism of action of the new dinuclear cis $\mathrm{Pt}^{\mathrm{II}}$ complex $\mathbf{1}$ containing a semi-rigid linker and for comparative purposes the molecular mechanism of action of a structurally cognate dinuclear cis $\mathrm{Pt}^{\mathrm{II}}$ complex containing a shorter, more rigid linker, $\left\{\left[\text { cis- } \mathrm{Pt}\left(\mathrm{NH}_{3}\right)_{2} \mathrm{Cl}\right]_{2}\left(\alpha, \alpha^{\prime}-\right.\right.$ diamino-p-xylene) $\}^{2+}$ (complex 2, Fig. 1) which are related to DNA modification by these complexes, recognition of these modifications by proteins and DNA repair. Here, we describe experiments revealing (i) new details of the DNA binding mode of $\mathbf{1}$ and $\mathbf{2}$ in cell-free media; (ii) repair of DNA adducts of $\mathbf{1}$ and $\mathbf{2}$ (since the integrity of this process in human cells is a key indicator of the sensitivity of a tumor to platinum-based therapy [26]); (iii) recognition of DNA adducts of $\mathbf{1}$ and $\mathbf{2}$ by high-mobility-group (HMG)-domain proteins (since these proteins are involved in the cisplatin mechanism of action [25]); (iv) sensitization of breast cancer cells to $\mathbf{1}$ and $\mathbf{2}$ by steroid hormones.

\section{Materials and methods}

\subsection{Chemicals}

Cisplatin was obtained from Sigma (Prague, Czech Republic) (purity was $\geq 99.9 \%$ based on elemental and ICP trace analysis). Dinuclear $\mathrm{Pt}^{\mathrm{II}}$ complexes $\mathbf{1}$ and $\mathbf{2}$ were prepared as described previously [23, 27]. The stock solutions of platinum compounds were prepared in $10 \mathrm{mM} \mathrm{NaClO}_{4}$ and stored at $20^{\circ} \mathrm{C}$ in the dark. The concentrations of platinum complexes in the stock solutions were determined by flameless atomic absorption spectrometry (FAAS). The concentrations of the platinum complexes indicated in the present work are related to the whole compound (not to the Pt content in the case of the dinuclear complexes). Calf thymus (CT) DNA (42\% G + C, mean molecular mass ca. $20000 \mathrm{kDa})$ was prepared and 
characterized as described previously $[28,29]$. Plasmids, pUC19 [2686 base pairs (bp)] and pBR322 (4361 bp) were isolated according to standard procedures. Restriction endonucleases were purchased from New England Biolabs (Beverly, MA). Deoxyribonucleoside triphosphates were from Roche Diagnostics, GmbH (Mannheim, Germany). Agarose was from FMC BioProducts (Rockland, ME). Electrophoresis-grade acrylamide, N,N'methylenebisacrylamide, ethidium bromide (EtBr), urea, and dithiothreitol were from Merck KgaA (Darmstadt, Germany). Proteinase K and ATP were from Boehringer (Mannheim, Germany). Spermine, EZBlue Gel Staining Reagent, $\beta$-estradiol and progesterone were from Sigma (Prague, Czech Republic). Expression and purification of recombinant rat full-length HMGB1 protein $(\mathrm{HMG}=$ high mobility group) and its domains A (residues 1-84 [30]) and B (residues 85-180 [30]) (HMGB1a and HMGB1b, respectively) were carried out as described [30-32]. Nonidet P-40 was from Fluka (Prague, Czech Republic). SDS was from Serva (Heidelberg, Germany). Radioactive products were from Amersham (Arlington Heights, IL, USA). A cell-free extract (CFE) was prepared from the repair proficient HeLa S3 cell line as described [33, 34]. Streptavidin-coated magnetic beads (Dynabeads) and Biotin-14-dATP were from Invitrogen Dynal AS (Oslo, Norway).

\subsection{Cytotoxicity}

Cisplatin, $\mathbf{1}$ and $\mathbf{2}$ were dissolved in DMSO. Stock solutions of the compounds were freshly prepared before use. The final concentration of DMSO in cell culture medium did not exceed $0.25 \%$. The A2780 and A2780cisR human ovarian carcinoma cell lines (parent cisplatin sensitive and with acquired cisplatin resistance, respectively) were grown in RPMI 1640 medium (GIBCO) supplemented with gentamycin $(50 \mu \mathrm{g} / \mathrm{mL}$, Serva) and $10 \%$ heat inactivated fetal bovine serum (GIBCO). The acquired resistance of A2780cisR cells was 
maintained by supplementing the medium with $1 \mu \mathrm{M}$ cisplatin every second passage. The cells were cultured in a humidified incubator at $37^{\circ} \mathrm{C}$ in a $5 \% \mathrm{CO}_{2}$ atmosphere and subcultured 2-3 times a week with an appropriate plating density.

Cell death was evaluated by using a system based on the tetrazolium compound MTT [3(4,5-dimethylthiazol-2-yl)-2,5-diphenyltetrazolium bromide] which is reduced by living cells to yield a formazan product that can be detected colorimetrically [35]. The cells were seeded in 96 -well tissue cultured plates at a density of $10^{4}$ cells/well in $100 \mu \mathrm{L}$ of medium. After overnight incubation $(16 \mathrm{hr})$, the cells were treated with the platinum compounds at the final concentrations in the range of 0 to $128 \mu \mathrm{M}$ in a final volume of $200 \mu \mathrm{L} /$ well. After additional $72 \mathrm{hr} 10 \mu \mathrm{L}$ of a freshly diluted MTT solution $(2.5 \mathrm{mg} / \mathrm{mL})$ was added to each well and the plate was incubated at $37^{\circ} \mathrm{C}$ in a humidified $5 \% \mathrm{CO}_{2}$ atmosphere for $4 \mathrm{hr}$. At the end of the incubation period the medium was removed and the formazan product was dissolved in 100 $\mu \mathrm{L}$ of DMSO. The cell viability was evaluated by measurement of the absorbance at $570 \mathrm{~nm}$, using an Absorbance Reader SUNRICE TECAN SCHOELLER. IC $_{50}$ values were calculated from curves constructed by plotting cell survival (\%) versus drug concentration $(\mu \mathrm{M})$. All experiments were made in triplicate. The reading values were converted to the percentage of control (\% cell survival). Cytotoxic effects were expressed as $\mathrm{IC}_{50}$ (concentration inhibiting cell growth by $50 \%$ ).

\subsection{Platination reactions in cell-free media}

If not stated otherwise, DNA was incubated with the platinum complex in $10 \mathrm{mM}$ $\mathrm{NaClO}_{4}$ at $37^{\circ} \mathrm{C}$ in the dark. After $24 \mathrm{hr}$, the samples were exhaustively dialyzed against the medium required for subsequent biochemical or biophysical analysis. An aliquot of these 
samples was used to determine the value of $\mathrm{r}_{\mathrm{b}}$ by FAAS. Alternatively, DNA binding of $\mathbf{1}$ and

2 was studied using differential pulse polarography (DPP) [36].

\subsection{Recognition of DNA adducts by HMG-domain protein}

The EcoRI/PvuII restriction fragment (92 bp) from pUC19 plasmid was modified with cisplatin or complexes 1 or 2 to desired $r_{b}$ value in $0.01 \mathrm{M} \mathrm{NaClO}_{4}$ at $37^{\circ} \mathrm{C}$, in dark for $24 \mathrm{hr}$. Following the incubation or the optional radioactive labeling (by $\gamma-{ }^{32} \mathrm{P}$ ATP), the fragments were 3 '-end biotinylated using Biotin-14-dATP label and terminal deoxynucleotidyl transferase in terminal transferase buffer $\left(100 \mathrm{mM}\right.$ cacodylate buffer, $\mathrm{pH} 6.8 ; 5 \mathrm{mM} \mathrm{CoCl}_{2}$, $0.5 \mathrm{mM}$ dithiothreitol). Biotinylated DNA was attached to streptavidine coated magnetic beads in $1 \mathrm{M} \mathrm{NaCl}, 5 \mathrm{mM}$ Tris. $\mathrm{HCl} \mathrm{pH} 7.4$ and $0.5 \mathrm{mM}$ EDTA. The beads were washed three times in the same buffer. HMG protein was added to the beads carrying DNA and incubated on ice in $10 \mathrm{mM}$ HEPES, pH 7.5, $10 \mathrm{mM} \mathrm{MgCl}_{2}, 50 \mathrm{mM} \mathrm{LiCl}, 100 \mathrm{mM} \mathrm{NaCl}, 1 \mathrm{mM}$ spermidine and $0.05 \%$ Nonidet $\mathrm{P} 40$, in the presence of poly $(\mathrm{dI}-\mathrm{dC})$ as a competitor for $1 \mathrm{hr}$. The beads were then washed 2 times in the same buffer. Finally the protein was released with $0.04 \%$ sodium dodecyl sulfate (SDS). Following the addition of loading buffer (0.1 M Tris$\mathrm{HCl}, \mathrm{pH}$ 6.8; $2 \%$ SDS; $0.1 \mathrm{M}$ dithiothreitol, $10 \%$ glycerol, $0.25 \%$ bromphenol blue) the samples were heated for five minutes at $90^{\circ} \mathrm{C}$, electrophoresed on $15 \%$ SDS-PAGE (PAGE $=$ polyacryalamide gel electrophoresis) and stained with EZBlue gel staining reagent.

\subsection{DNA repair synthesis by human cell extract}

Repair DNA synthesis of CFEs was assayed using pUC19 plasmid. Each reaction of 50 $\mu \mathrm{L}$ contained $600 \mathrm{ng}$ of nonmodified pBR322 and $600 \mathrm{ng}$ of nonmodified or platinated 
pUC19, $2 \mathrm{mM}$ ATP, $30 \mathrm{mM} \mathrm{KCl}, 0.05 \mathrm{mg} / \mathrm{mL}$ creatine phosphokinase (rabbit muscle), 20 mM each dGTP, dATP, and dTTP, $8 \mathrm{mM} \mathrm{dCTP,} 74 \mathrm{kBq}$ of $\left[\alpha-{ }^{32} \mathrm{P}\right] \mathrm{dCTP}$ in the buffer composed of $40 \mathrm{mM}$ HEPES-KOH, $\mathrm{pH} 7.5,5 \mathrm{mM} \mathrm{MgCl} 2,0.5 \mathrm{mM}$ dithiothreitol, $22 \mathrm{mM}$ creatine phosphate, $1.4 \mathrm{mg}$ of bovine serum albumin/mL, and $20 \mu \mathrm{g}$ of CFE from the HeLa S3 cells. Reactions were incubated for $3 \mathrm{hr}$ at $30^{\circ} \mathrm{C}$ and terminated by adding EDTA to a final concentration of $20 \mathrm{mM}$, SDS to $0.6 \%$, and proteinase $\mathrm{K}$ to $250 \mu \mathrm{g} / \mathrm{mL}$ and then incubating for $20 \mathrm{~min}$. The products were extracted with one volume of 1:1 phenol/chloroform. The DNA was precipitated from the aqueous layer by the addition of 0.1 volume of $3 \mathrm{M}$ sodium acetate and 2.5 volumes of ethanol. After $30 \mathrm{~min}$ of incubation at $-20^{\circ} \mathrm{C}$ and centrifugation at $12000 \mathrm{~g}$ for $30 \mathrm{~min}$ at $4{ }^{\circ} \mathrm{C}$, the pellet was washed with $0.2 \mathrm{~mL}$ of $80 \%$ ethanol and dried in a vacuum centrifuge. DNA was finally linearized by SspI before electrophoresis on a 1\% agarose gel. Resulting gel was stained by EtBr. The experiments were made in quadruplicate.

\subsection{Sensitization of cancer cells by steroid hormones to platinum complexes by clonogenic} assay

MCF-7 cells were seeded on $6 \mathrm{~cm}$ Petri dishes at a density of 400 cells per dish. After 24 $\mathrm{hr}$, a fresh stock solution containing steroid hormone(s), estradiol or estradiol plus progesterone, was prepared in $N, N$-dimethylformamide and added to the dishes so that a final concentration of each hormone was $0.2 \mu \mathrm{M}$. Control dishes were treated with the same volume of $N, N$-dimethylformamide without hormone. The hormone was added at the same time as platinum complex $(\mathbf{1}, \mathbf{2}$, or cisplatin). After $4 \mathrm{hr}$ treatment, the cells were washed with PBS, and fresh medium was added. After 10 days, the cell colonies were stained with $1 \%$ methylene blue and were then counted. Each point is an average of six independent determinations. 


\subsection{Other physical methods}

Absorption spectra were measured with a Beckmann DU-7400 spectrophotometer. FAAS measurements were carried out with a Varian AA240Z Zeeman atomic absorption spectrometer equipped with a GTA 120 graphite tube atomizer. For FAAS analysis DNA was precipitated with ethanol and dissolved in $0.1 \mathrm{M} \mathrm{HCl}$. The gels were visualized by using the BAS 2500 FUJIFILM bioimaging analyzer, and the radioactivities associated with bands were quantitated with the AIDA image analyzer software (Raytest, Germany).

\section{Results}

\subsection{Cytotoxicity}

The cytotoxic activity of the $\mathbf{1}$ and $\mathbf{2}$ tested in the present work was determined against A2780 (parent cisplatin sensitive) and A2780cisR (with acquired cisplatin resistance) human ovarian carcinoma cell lines, commonly used to test cytotoxic activity of cisplatin analogues and other antitumor metallodrugs. The tumor cell lines were incubated for $72 \mathrm{hr}$ with the platinum compounds and the cell survival in the culture treated with the platinum compounds was evaluated as described in the section Experimental Procedures. Results (Table 1) show that the cytotoxicity of $\mathbf{1}$ in cisplatin sensitive A2780 cells was comparable to the cytotoxicity of cisplatin, whereas $\mathbf{2}$ was slightly less cytotoxic. Importantly, both $\mathbf{1}$ and $\mathbf{2}$ were markedly more active in the cisplatin-resistant line A2780cisR and again 2 was less cytotoxic (Table 1). 


\subsection{Repair DNA synthesis by human cell extracts}

To investigate "downstream" effects of DNA damage by adducts of $\mathbf{1}$ and $\mathbf{2}$, we used in vitro systems to study repair of platinum lesions by CFE. DNA repair efficiency in pUC19 plasmid (2686 bp) globally modified by $\mathbf{1}, 2$ or cisplatin (for comparative purposes) at $r_{b}=$ 0.03 ( $\mathrm{r}_{\mathrm{b}}$ is defined as the number of molecules of the platinum complex bound per nucleotide residue) was tested using CFE of repair proficient HeLa cells. Repair activity was monitored by measurement of the amount of incorporated radiolabelled nucleotide. The incorporation of radioactive material was corrected for the relative DNA content in each band. As illustrated in Fig. 2, damage-induced DNA repair synthesis detected in the plasmid modified by $\mathbf{1}$ or $\mathbf{2}$ was approximately 38 or $36 \%$, respectively, of that found for the cisplatin at the same level of modification.

\subsection{DNA modification in a cell-free medium}

The cellular DNA repair response strongly depends on the character and extent of DNA damage. Therefore, it was of great interest to characterize DNA distortions induced by $\mathbf{1}$ and 2. With the view of this we examined the DNA binding properties of these complexes and compared them with those of cisplatin. The experiments were aimed at quantification of the binding of $\mathbf{1}$ and $\mathbf{2}$ to mammalian DNA, determination of their preferential binding sites, and characterization of DNA lesions induced by $\mathbf{1}$ and $\mathbf{2}$ within natural DNA. The results of these experiments are described in detail in the Supplemental Information and are summarized in the following paragraph. 


\subsubsection{DNA binding}

CT DNA was incubated with the platinum complexes at $r_{i}$ values of $0.01,0.03,0.05$, and $0.1)\left(r_{i}\right.$ is defined as the molar ratio of free platinum complex to nucleotides at the onset of incubation with DNA) in $10 \mathrm{mM} \mathrm{NaClO}_{4}$ at $37^{\circ} \mathrm{C}$ for 24 or $48 \mathrm{hr}$. The amount of the platinum compound bound to DNA increased with time. In this binding reaction the time at which the binding reached $50 \%\left(\mathrm{t}_{50 \%}\right)$ was $14.9 \pm 0.6 \mathrm{~min}$ and $39 \pm 6 \mathrm{~min}$ for $\mathbf{1}$ and $\mathbf{2}$, respectively, and both complexes were quantitatively bound after $24 \mathrm{hr}$. This result indicates that the rate of binding of both 1 and $\mathbf{2}$ to natural double-helical DNA is higher than that of cisplatin $\left(\mathrm{t}_{50 \%}=\right.$ ca. $120 \mathrm{~min}$ [37]), although cisplatin is also quantitatively bound to DNA after $24 \mathrm{hr}$ under identical experimental conditions [37].

\subsubsection{Transcription mapping of platinum-DNA adducts}

In vitro RNA synthesis by T7 and SP6 RNA polymerases on DNA templates containing adducts of $\mathbf{1}$ or $\mathbf{2}$ revealed (Fig. S1) that the major stop sites produced by these complexes were at guanine residues, a few stop sites were also at adenine and cytosine residues. These results also suggest that the adducts formed by $\mathbf{1}$ and $\mathbf{2}$ are able to inhibit RNA polymerase.

\subsubsection{Interstrand cross-linking}

We quantitated the interstrand cross-linking efficiency of $\mathbf{1}$ and $\mathbf{2}$ in linearized pUC19 plasmid (Fig. S2). The interstrand cross-linking efficiencies (defined as the number of interstrand crosslinks per one adduct of the platinum complex [17]) of both $\mathbf{1}$ and 2 (48 $\pm 4 \%$ and $20 \pm 2 \%$, respectively) were significantly higher than that of cisplatin (6\% [38]).

\subsubsection{Characterization of DNA adducts by ethidium bromide fluorescence}


The results of these experiments (Fig. S3) suggest that the conformational distortion induced in DNA by the adducts of $\mathbf{1}$ is more delocalized and extends over more base pairs around the platination sites than in the case of the adducts of $\mathbf{2}$ or mononuclear cisplatin. Thus, these results are consistent with the formation of long-range intra- or interstrand CLs of 1, whereas 2 apparently forms in DNA much less long-range lesions. In aggregate, characterization of DNA adducts of $\mathbf{1}$ and $\mathbf{2}$ by EtBr fluorescence supports the view that the DNA binding modes of these dinuclear platinum compounds are distinctly different.

\subsubsection{Unwinding of negatively supercoiled DNA}

Electrophoresis in native agarose gel was used to quantify the unwinding induced in pUC19 plasmid by adducts of $\mathbf{1}$ and $\mathbf{2}$ by monitoring the degree of supercoiling (Fig. S4). We determined the DNA unwinding angle of $17^{\circ}$ for the adduct of 1 and $12^{\circ}$ for that of 2 . The high level of unwinding induced by $\mathbf{1}$ and $\mathbf{2}$ is notable. Interestingly, the unwinding angle produced by $\mathbf{1}$ is higher than that produced by $\mathbf{2}$. One plausible explanation for this observation might be consistent with a possibility that the additional contribution to unwinding is associated with the interaction of the linker chain of $\mathbf{1}$ with the duplex upon covalent binding of platinum units. Thus, the results of unwinding experiments represent another support for the view that structure of DNA lesions formed by $\mathbf{1}$ is substantially different from the structure of DNA adducts of its counterpart 2.

\subsection{Recognition of DNA adducts by high-mobility-group (HMG)-domain proteins}

The altered structures induced in DNA by cisplatin and its analogs attract HMG-domain and other proteins $[30,39]$. This binding of HMG-domain proteins to DNA modified by cisplatin and its analogs has been postulated to mediate the antitumor properties of these 
drugs.[39] As dinuclear platinum complexes $\mathbf{1}$ and $\mathbf{2}$ exhibit antitumor activity qualitatively different from cisplatin, it was of interest to examine whether also the adducts formed within DNA by $\mathbf{1}$ or $\mathbf{2}$ are able to be specifically recognized by HMG domain proteins.

To assess the ability of HMGB1 protein to recognize DNA modified by complexes $\mathbf{1}$ and 2 we employed the system of DNA immobilized on streptavidine coated magnetic beads suspended in HMG binding buffer containing HMGB1 protein. $10 \mu \mathrm{g}$ of DNA fragment was immobilized on $1 \mathrm{mg}$ of Dynabeads. Radioactively labeled DNA enabled us to ensure the same quantity of DNA in various samples. First we determined whether HMGB1 protein exhibits the ability to recognize DNA modified by the two new dinuclear compounds. Immobilized DNA (nonmodified or modified by cisplatin, complex $\mathbf{1}$ and $\mathbf{2}$ to $\mathrm{r}_{\mathrm{b}}=0.02$ ) was incubated with HMGB1 protein on ice for $1 \mathrm{hr}$ in the presence of poly $(\mathrm{dI}-\mathrm{dC})$ as a competitor. Following the incubation, DNA was washed extensively and bound protein was released in $0.04 \%$ SDS and electrophoresed on $15 \%$ SDS-PAGE.

The HMGB1 protein was found to bind DNA modified by cisplatin, in agreement with experiments published earlier $[40,41]$ that was evidenced by the presence of band migrating near the $34 \mathrm{kDa}$ marker corresponding to HMGB1 protein (Fig. 3A, lane cisPt, Table S1). Interestingly, the band corresponding to HMGB1 was also clearly seen for the probe modified by 1 (Fig. 3A, lane 1); the intensity of this band was almost comparable (80\%) to that found for cisplatin (Table S1). On the other hand, much less effective binding of the HMGB1 to the DNA containing the adducts of $\mathbf{2}$ was detected, the amount of HMGB1 protein bound to this probe was only $15 \%$ of the amount of HMGB1 bound to DNA modified by cisplatin under the same conditions (Fig. 3A, lane 2, Table S1). No binding of the proteins occurred under identical experimental conditions if the same DNA probe was unplatinated (Fig. 3A, lane NoPt). These results clearly showed that DNA modified by $\mathbf{1}$ is efficiently recognized by HMGB1 with relatively high affinity, though slightly less than to the probe containing the 
adducts of cisplatin. In contrast, DNA adducts of $\mathbf{2}$ are recognized by this protein markedly less.

To determine which of the two HMGB1 domains A or B predominates in recognition and binding of DNA lesions of $\mathbf{1}$, the binding of HMGB1 domain A and HMGB1 domain B to the DNA modified by complexes 1 or 2 was investigated (Fig. 3 B,C). The experiments revealed that in agreement with previously published data [41], HMGB1a effectively bound to the probe containing adducts of cisplatin (Fig. 3B, lane cisPt). Considerably weaker binding of HMGB1a was noticed to the probes containing adducts of $\mathbf{1}$ or $\mathbf{2}$; relative amount of HMGB1a protein bound to DNA probe containing adducts of cisplatin, $\mathbf{1}$ or $\mathbf{2}$ was $100 \%$, $20 \%$, or $14 \%$, respectively (Fig. 3B, Table S1). On the other hand, the amount of HMGB1b bound to the DNA modified by 1 was two-fold higher compared to that bound to DNA modified by cisplatin (Fig. 3C, Table S1). These results clearly show that DNA damaged by complex 1 was recognized by HMGB1 protein, but in contrast to DNA globally modified by cisplatin, the full-length HMGB1 protein binds to DNA globally modified by $\mathbf{1}$ mainly through domain B.

Complex 1 modifies DNA so that it forms approximately equal amounts of interstrand and intrastrand adducts (see paragraph Interstrand cross-linking in this Section and Fig. S2). To distinguish which type of lesions formed by $\mathbf{1}$ within DNA is preferentially recognized by HMGB1 protein, the following experiment was performed. The $92 \mathrm{bp}$ fragment of DNA was modified by $\mathbf{1}$ so that the fragment contained only one adduct per DNA fragment on average. After the modification, DNA was loaded into the denaturating agarose gel and two DNA fractions were purified from the gel, one contained only intrastrand adducts (no interstrand CLs) (F-IAA) and the other contained at least one interstrand CL (F-IEC). These two separated DNA fractions were then allowed to interact with HMGB1b, as described in section Experimental procedures. The amount of HMGB1b protein bound to each DNA fraction was 
determined by SDS/PAGE electrophoresis. The inspection of the electrophoreogram (Fig. 4) revealed that HMGB1b bound to DNA containing interstrand CLs of 1 whereas it bound considerably less (4-fold) to DNA modified by 1 to the similar level but containing other adducts, but not interstrand CLs (Table S2).

\subsection{Steroid hormones sensitize cancer cells to complex 1 , but not to complex 2}

Previous studies have shown that HMGB1 protein sensitizes cells to cisplatin by shielding its DNA adducts from nucleotide excision repair [25, 42]. Human breast cancer cells MCF-7 contain estrogen and progesterone receptors and respond to these steroids upregulating HMGB1 protein [43]. Importantly, treatment of these cancer cells with estrogen or progesterone significantly increases the potency of cisplatin apparently owing to the overexpression of HMGB1 [44]. Since DNA adducts of 1 are recognized by HMGB1 protein markedly more than those of 2 (Fig. 3), it was of interest to assess the involvement of HMGdomain proteins in mediating cytotoxicity of the dinuclear $\mathrm{Pt}^{\mathrm{II}}$ complexes tested in the present work. Therefore, we investigated the effects of elevated HMGB1 levels due to steroid hormone treatment in MCF-7 cells on the sensitivity of these cells to 1 or 2 (Fig. 5) using clonogenic assay in the same way as described previously for cisplatin and carboplatin [44]. As anticipated, we found that elevated HMGB1 expression levels were paralleled by increased sensitivity toward 1, but markedly less toward 2 (Fig. 5 and Table S4). For instance, in MCF-7 cells, estradiol or estradiol plus progesterone treatment increased sensitivity toward 1 about 2.7- or 4.2-fold, respectively, when only 50\% of the cells are viable (Fig. 5A); estradiol or estradiol plus progesterone treatment also increased sensitivity toward cisplatin, but only about 1.8- or 2.5-fold, respectively (Fig. 5C). Thus, sensitivity toward $\mathbf{1}$ was enhanced due to steroid hormone treatment even considerably more than toward cisplatin. 
Sensitivity of MCF-7 cells, treated with hormones, toward 1, 2, and cisplatin was also determined by MTT assay (Table S3). The trend was similar to that observed when clonogenic assay was used, although $\mathrm{IC}_{50}$ data obtained by MTT assay were uniformly higher than in clonogenic assay.

\section{Discussion}

We demonstrate in the present work that the dinuclear complexes $\mathbf{1}$ and $\mathbf{2}$ are quite toxic to the ovarian tumor cells, with $\mathrm{IC}_{50}$ values that were comparable to that observed for cisplatin in the cisplatin sensitive cell line A2780, and noticeably much lower in the cisplatin-resistant line A2780cisR (Table 1). Thus, these results complement those obtained in the previous study [27] showing that complexes $\mathbf{1}$ and $\mathbf{2}$ exhibit the promising cytotoxicity to the human nonsmall-cell lung cancer cell line (A549). Interestingly, the cytotoxicity of both $\mathbf{1}$ and $\mathbf{2}$ to the ovarian tumor cells is characterized by remarkably low resistance factors, equal to or even less than $\mathbf{1}$, which indicates that the dinuclear platinum complexes examined in the present work are capable of circumventing of cisplatin resistance in some types of the cisplatinresistant lines. In aggregate, no cross-resistance to cisplatin and high cytotoxic effects in cisplatin resistant cells represent important pharmacological features of $\mathbf{1}$ and $\mathbf{2}$.

An important feature of the mechanism underlying antitumor effects of DNA-binding metal-based compounds is repair of their DNA adducts $[40,45]$. A persistence of these DNA adducts may potentiate their antitumor effects in the cells sensitive to these compounds $[8,39$, 40]. DNA repair synthesis was investigated in the present work using the CFE from human tumor cells and DNA substrates randomly modified by $\mathbf{1}$ or $\mathbf{2}$. Importantly, the adducts of both 1 and $\mathbf{2}$ induced a considerably lower level of repair synthesis than the adducts of 
cisplatin suggesting a less efficient removal from DNA and enhanced persistence of the adducts of the dinuclear complexes $\mathbf{1}$ and $\mathbf{2}$. Thus, enhanced resistivity of DNA adducts of $\mathbf{1}$ and $\mathbf{2}$ against repair processes appears to be an important factor contributing to ability of $\mathbf{1}$ and 2 to overcome resistance towards cisplatin.

Structural features of DNA distortions are considered to be major factors playing a key role in recognition by damaged-DNA recognition-proteins and DNA repair systems. The analysis of DNA binding of $\mathbf{1}$ and $\mathbf{2}$ described in this report and summarized in Table 2 provides experimental support for the view that the binding of these dinuclear platinum complexes modifies DNA in a way which is in several aspects considerably different from modification of DNA by "conventional" mononuclear cisplatin. These differences may suggest that in comparison with adducts of cisplatin the reduced repair of DNA adducts of the dinuclear $\mathrm{Pt}^{\mathrm{II}}$ complexes is a consequence of their different DNA binding mode.

The binding of $\mathbf{1}$ and $\mathbf{2}$ to DNA is considerably faster than the binding of dichloro derivatives of mononuclear $\mathrm{Pt}^{\mathrm{II}}$ complexes, such as cisplatin or transplatin $\left(\mathrm{t}_{50 \%} \sim 120 \mathrm{~min}\right.$ [37]) likely reflecting the higher charge. In addition, the different rate of the binding of $\mathbf{1}$ and 2 may be associated with the differences in the linking chains, such as flexibility and hydrophobicity, which may affect pre-association step of DNA binding [46, 47].

Importantly, the effect of the linker character and geometry results in enhanced extent of the long-range delocalized cross-linking by $\mathbf{1}$ as revealed by fluorescence measurements with EtBr (Fig. S3). Similarly, DNA interstrand cross-linking by 1 is enhanced compared with that by 2 (Fig. S2, Table 2). This enhanced interstrand crosslinking efficiency of 1 correlates with its higher potency compared with that of $\mathbf{2}$ so that interstrand CLs appear to play the prevalent role in cytotoxicity of $\mathbf{1}$. In addition, compared with $\mathbf{2}, \mathbf{1}$ distorts DNA secondary structure differently and unwinds DNA more (Fig. S4 and Table 2). Thus, it is reasonable to expect that several "downstream" intracellular effects of DNA adducts of $\mathbf{1}$ and $\mathbf{2}$ are different. 
Consistent with this view is the observation that affinity of HMG-domain proteins to DNA adducts of $\mathbf{1}$ is markedly higher than that to DNA adducts of $\mathbf{2}$ (Fig. 3A). The fulllength HMGB1 protein consists of two tandem HMG box domains (A and B) and a Cterminal acidic tail. Both A and B domains of HMGB1 protein share a common HMG box structure. Domain A has a higher binding affinity to distorted DNA than domain B, whereas domain B bends DNA more effectively [48]. Because of the importance of the HMG box interaction with DNA [25], the studies of the individual HMG domains and their DNA complexes are of great interest. It has been shown that full-length HMGB1 protein binds to DNA containing a site-specific 1,2-GG intrastrand CL of cisplatin mainly through domain A, whereas domain B alone binds cisplatinated DNA much more weakly than domain A alone [41]. In contrast to these data, binding of full-length HMGB1 to DNA modified by the dinuclear complex $\mathbf{1}$ is mediated preferentially by domain B (Fig. 3B, C). This result, in combination with our previous findings that the domain B of the HMGB1 protein with the A/B linker plays a crucial role in the interaction between full-length HMGB1 protein and DNA interstrand cross-linked by cisplatin [30], implies a possible role of the interstrand DNA adducts of $\mathbf{1}$ in the interaction with HMG-domain proteins. Therefore, we tested the contribution of DNA intrastrand and interstrand adducts formed by $\mathbf{1}$ to the binding of HMGB1 to DNA globally modified by $\mathbf{1}$. The sample containing DNA fragment globally modified by 1 was divided into two DNA fractions, one containing only intrastrand adducts (no interstrand CLs) and the other containing interstrand CLs and the affinity of HMGB1b towards these two fractions was tested. The results unambiguously show the prevalent role of DNA interstrand CLs of $\mathbf{1}$ in recognition and binding of DNA modified by $\mathbf{1}$ to full-length HMGB1 protein. To our knowledge, this is the first evidence for strong specific recognition and binding of HMG-domain proteins to DNA modified by a polynuclear platinum complex. Previously, a weak recognition of DNA interstrand CLs of $\left[\left\{\right.\right.$ trans- $\left.\mathrm{PtCl}\left(\mathrm{NH}_{3}\right)_{2}\right\} \mathrm{H}_{2} \mathrm{~N}\left(\mathrm{CH}_{2}\right)_{2}$ - 
$\left.{ }_{6} \mathrm{NH}_{2}\right] \mathrm{Cl}_{2}$ complexes by full-length HMGB1 protein has only been reported [7], whereas a recognition of intrastrand CLs of these complexes has not been detected.

The results of the present work provide evidence that HMGB1 domain B controls a relatively strong binding of full-length HMGB1 to DNA modified by 1 when both domain A and $\mathrm{B}$ are present. It is quite conceivable that domain B is the dominating domain in HMGB1 protein that binds to the interstrand $\mathrm{CL}$ of $\mathbf{1}$, while domain A only facilitates binding by providing additional protein-DNA interactions. A structure of full-length HMGB1 complexed with DNA containing interstrand CL of 1 will provide more insights into how HMG-domain proteins can mediate cytotoxicity of $\mathbf{1}$. On the other hand, the affinities of full-length HMGB1 protein and its domain A to DNA modified by 2 are relatively weak and almost identical. This result is consistent with the view and supports the hypothesis that the binding of full-length HMGB1 protein to DNA modified by the dinuclear complex 2, although relatively weak, is mediated preferentially by the domain A. Collectively, the results of this work demonstrate that not only DNA binding modes of $\mathbf{1}$ and $\mathbf{2}$ and resulting conformational alterations are noticeably different, but also "downstream" intracellular effects of DNA adducts of the two dinuclear complexes may be different, particularly in the cells in which the HMGB1 level is high and in which HMGB1 protein is not prevented from interacting with platinum-modified DNA.

It has been shown that specific interaction between adducts of "conventional" cisplatin and cellular HMG-domain proteins modulate the sensitivity of tumor cells to this drug. In particular, protein-DNA interactions induced by cisplatin inhibit replication,[49] shield the adducts from nucleotide excision repair [50] and interfere with transcription by recruiting transcription factors from their native binding sites [51, 52]. Therefore, it is reasonable to assume that such interactions may also differently modulate the cellular responses both to the 
platinum dinuclear complexes $\mathbf{1}$ and $\mathbf{2}$ and also to the class of dinuclear complexes tested in the present work and cisplatin.

In conclusion, the results of the present work are consistent with the hypothesis that the unique properties of interstrand CLs of the class of bifunctional polynuclear platinum complexes tested in the present work and resulting conformational alterations in DNA have critical consequences for their antitumor effects. An interesting finding that might be also translated to the clinical trials is that treatment leading to enhancement of level of HMGdomain proteins in tumor cells should allow the regimens involving $\mathbf{1}$ to show increased antitumor effects toward these cells.

\section{Acknowledgements}

This research was supported by the Ministry of Education of the CR (MSMT LC06030, 6198959216, ME08017, ME10066, OC08003, and OC09018), the Academy of Sciences of the Czech Republic (Grants KAN200200651, M200040901, AV0Z50040507, and AV0Z50040702), the Grant Agency of the Academy of Sciences of the CR (IAA400040803), and the Grant Agency of the CR (301/09/H004 and P301/10/0598). Financial support from the National Natural Science Foundation of China (No. 90713001) is also acknowledged. J.K. is an international research scholar of the Howard Hughes Medical Institute. The authors also acknowledge that their participation in the EU COST Action D39 has enabled them to exchange regularly their most recent ideas in the field of anticancer metallodrugs with several European colleagues.

\section{Appendix A. Supplementary data}

Supplementary data associated with this article can be found, in the online version, at doi: ... 


\section{References}

[1] Pratesi G, Perego P, Polizzi D, Righetti SC, Supino R, Caserini C, et al. A novel charged trinuclear platinum complex effective against cisplatin-resistant tumours: hypersensitivity of p53-mutant human tumour xenografts. Br J Cancer 1999;80:1912-9.

[2] Farrell N. Polynuclear platinum drugs. In: Sigel A, Sigel H, editors. Metal ions in biological systems. New York, Basel: Marcel Dekker, Inc.; 2004, p. 251-96.

[3] Brabec V, Kasparkova J. Modifications of DNA by platinum complexes: Relation to resistance of tumors to platinum antitumor drugs. Drug Resist Updat 2005;8:131-46.

[4] Brabec V, Kasparkova J. DNA interactions of platinum anticancer drugs. Recent advances and mechanisms of action. In: Perez-Martin J-M, Fuertes MA, Alonso C, editors. Metal compounds in cancer chemotherapy. Trivandrum, Kerala (India): Research Signpost; 2005, p. 187-218.

[5] Brabec V, Christofis P, Slamova M, Kostrhunova H, Novakova O, Najajreh Y, et al. DNA interactions of new cytotoxic tetrafunctional dinuclear platinum complex trans, trans-[ $\left\{\mathrm{PtCl}_{2}\left(\mathrm{NH}_{3}\right)\right\}_{2}$ (piperazine)]. Biochem Pharmacol 2007;73:1887-900.

[6] Cossa G, Gatti L, Zunino F, Perego P. Strategies to improve the efficacy of platinum compounds. Curr Med Chem 2009;16:2355-65.

[7] Kasparkova J, Farrell N, Brabec V. Sequence specificity, conformation, and recognition by HMG1 protein of major DNA interstrand cross-links of antitumor dinuclear platinum complexes. J Biol Chem 2000;275:15789-98.

[8] Kasparkova J, Zehnulova J, Farrell N, Brabec V. DNA interstrand cross-links of the novel antitumor trinuclear platinum complex BBR3464. Conformation, recognition by 
high mobility group domain proteins, and nucleotide excision repair. J Biol Chem 2002;277:48076-86.

[9] Brabec V, Kasparkova J, Vrana O, Novakova O, Cox JW, Qu Y, et al. DNA modifications by a novel bifunctional trinuclear platinum Phase I anticancer agent. Biochemistry 1999;38:6781-90.

[10] Kasparkova J, Novakova O, Vrana O, Farrell N, Brabec V. Effect of geometric isomerism in dinuclear platinum antitumor complexes on DNA interstrand crosslinking. Biochemistry 1999;38:10997-1005.

[11] Zehnulova J, Kasparkova J, Farrell N, Brabec V. Conformation, recognition by high mobility group domain proteins, and nucleotide excision repair of DNA intrastrand cross-links of novel antitumor trinuclear platinum complex BBR3464. J Biol Chem 2001;276:22191-9.

[12] Roberts JD, Peroutka J, Farrell N. Cellular pharmacology of polynuclear platinum anticancer agents. J Inorg Biochem 1999;77:51-7.

[13] Roberts JD, Beggiolin G, Manzotti C, Piazzoni L, Farrell N. Comparison of cytotoxicity and cellular accumulation of polynuclear platinum complexes in L1210 murine leukemia cell lines. J Inorg Biochem 1999;77:47-50.

[14] Servidei T, Ferlini C, Riccardi A, Meco D, Scambia G, Segni G, et al. The novel trinuclear platinum complex BBR3464 induces a cellular response different from cisplatin. Eur J Cancer 2001;37:930-8.

[15] Farrell N. Polynuclear charged platinum compounds as a new class of anticancer agents: Toward a new paradigm. In: Kelland LR, Farrell NP, editors. Platinum-based drugs in cancer therapy. Totowa/NJ: Humana Press Inc.; 2000, p. 321-38.

[16] Harris AL, Yang X, Hegmans A, Povirk L, Ryan JJ, Kelland L, et al. Synthesis, characterization, and cytotoxicity of a novel highly charged trinuclear platinum 
compound. Enhancement of cellular uptake with charge. Inorg Chem 2005;44:9598600.

[17] Farrell N, Qu Y, Feng L, Van Houten B. Comparison of chemical reactivity, cytotoxicity, interstrand cross-linking and DNA sequence specificity of bis(platinum) complexes containing monodentate or bidentate coordination spheres with their monomeric analogues. Biochemistry 1990;29:9522-31.

[18] Summa N, Maigut J, Puchta R, van Eldik R. Possible biotransformation reactions of polynuclear Pt(II) complexes. Inorg Chem 2007;46:2094-104.

[19] Oehlsen ME, Qu Y, Farrell N. Reaction of polynuclear platinum antitumor compounds with reduced glutathione studied by multinuclear $\left({ }^{1} \mathrm{H},{ }^{1} \mathrm{H}-{ }^{15} \mathrm{~N}\right.$ gradient heteronuclear single-quantum coherence, and ${ }^{195} \mathrm{Pt}$ ) NMR spectroscopy. Inorg Chem 2003;42:5498 506.

[20] Billecke C, Finniss S, Tahash L, Miller C, Mikkelsen T, Farrell NP, et al. Polynuclear platinum anticancer drugs are more potent than cisplatin and induce cell cycle arrest in glioma. Neuro Oncol 2006;8:215-26.

[21] Mitchell C, Kabolizadeh P, Ryan J, Roberts JD, Yacoub A, Curiel DT, et al. Low-dose BBR3610 toxicity in colon cancer cells is p53-independent and enhanced by inhibition of epidermal growth factor receptor (ERBB1)-Phosphatidyl inositol 3 kinase signaling. Mol Pharmacol 2007;72:704-14.

[22] Williams JW, Qu Y, Bulluss GH, Alvorado E, Farrell NP. Dinuclear platinum complexes with biological relevance based on the 1,2-diaminocyclohexane carrier ligand. Inorg Chem 2007;46:5820-2.

[23] Fan D, Yang X, Wang X, Zhang S, Mao J, Ding J, et al. A dinuclear monofunctional platinum(II) complex with an aromatic linker shows low reactivity towards glutathione 
but high DNA binding ability and antitumor activity. J Biol Inorg Chem 2007;12:65565.

[24] Jamieson ER, Lippard SJ. Structure, recognition, and processing of cisplatin-DNA adducts. Chem Rev 1999;99:2467-98.

[25] Jung Y, Lippard SJ. Direct cellular responses to platinum-induced DNA damage. Chem Rev 2007;107:1387-407.

[26] Brabec V, Kasparkova J. Role of DNA repair in antitumor effects of platinum drugs. In: Hadjiliadis N, Sletten E, editors. Metal complex - DNA interactions. Chichester, UK: Wiley; 2009, p. 175-208.

[27] Zhu J, Lin M, Fan D, Wu Z, Zhang J, Luc Y, et al. The role of bridging ligands in determining DNA-binding ability and cross-linking patterns of dinuclear platinum(II) antitumor complexes. Dalton Trans 2009:10889 -95.

[28] Brabec V, Palecek E. The influence of salts and $\mathrm{pH}$ on polarographic currents produced by denatured DNA. Biophysik 1970;6:290-300.

[29] Brabec V, Palecek E. Interaction of nucleic acids with electrically charged surfaces. II. Conformational changes in double-helical polynucleotides. Biophys Chem 1976;4:7692.

[30] Kasparkova J, Delalande O, Stros M, Elizondo-Riojas MA, Vojtiskova M, Kozelka J, et al. Recognition of DNA interstrand cross-link of antitumor cisplatin by HMGB1 protein. Biochemistry 2003;42:1234-44.

[31] Stros M. DNA bending by the chromosomal protein HMG1 and its high mobility group box domains. Effect of flanking sequences. J Biol Chem 1998;273:10355-61.

[32] Stros M. Two mutations of basic residues within the N-terminus of HMG-1 B domain with different effects on DNA supercoiling and binding to bent DNA. Biochemistry 2001;40:4769-79. 
[33] Reardon JT, Vaisman A, Chaney SG, Sancar A. Efficient nucleotide excision repair of cisplatin, oxaliplatin, and bis-aceto-ammine-dichloro-cyclohexylamine-platinum(IV) (JM216) platinum intrastrand DNA diadducts. Cancer Res 1999;59:3968-71.

[34] Manley JL, Fire A, Cano A, Sharp PA, Gefter ML. DNA-dependent transcription of adenovirus genes in a soluble whole-cell extract. Proc Natl Acad Sci USA $1980 ; 77: 3855-9$.

[35] Alley MC, Scudiero DA, Monks A, Hursey ML, Czerwinski MJ, Fine DL, et al. Feasibility of drug screening with panels of human tumor cell lines using a microculture tetrazolium assay. Cancer Res 1988;48:589-601.

[36] Kim SD, Vrana O, Kleinwächter V, Niki K, Brabec V. Polarographic determination of subnanogram quantities of free platinum in reaction mixture with DNA. Anal Lett 1990;23:1505-18.

[37] Bancroft DP, Lepre CA, Lippard SJ. ${ }^{195} \mathrm{Pt}$ NMR kinetic and mechanistic studies of cisdiamminedichloroplatinum and trans-diamminedichloroplatinum(II) binding to DNA. J Am Chem Soc 1990;112:6860-71.

[38] Brabec V, Leng M. DNA interstrand cross-links of trans-diamminedichloroplatinum(II) are preferentially formed between guanine and complementary cytosine residues. Proc Natl Acad Sci USA 1993;90:5345-9.

[39] Brabec V. DNA modifications by antitumor platinum and ruthenium compounds: their recognition and repair. Prog Nucleic Acid Res Mol Biol 2002;71:1-68.

[40] Cohen SM, Lippard SJ. Cisplatin: From DNA damage to cancer chemotherapy. Prog Nucleic Acid Res Mol Biol 2001;67:93-130.

[41] Jung YW, Lippard SJ. Nature of full-length HMGB1 binding to cisplatin-modified DNA. Biochemistry 2003;42:2664-71. 
[42] Huang JC, Zamble DB, Reardon JT, Lippard SJ, Sancar A. HMG-domain proteins specifically inhibit the repair of the major DNA adduct of the anticancer drug cisplatin by human excision nuclease. Proc Natl Acad Sci USA 1994;91:10394-8.

[43] Chau KY, Lam HYP, Lee KLD. Estrogen treatment induces elevated expression of HMG1 in MCF-7 cells. Exp Cell Res 1998;241:269-72.

[44] He Q, Liang CH, Lippard SJ. Steroid hormones induce HMG1 overexpression and sensitize breast cancer cells to cisplatin and carboplatin. Proc Natl Acad Sci USA 2000;97:5768-72.

[45] Brabec V, Kasparkova J. Molecular aspects of resistance to antitumor platinum drugs. Drug Resist Updat 2002;5:147-61.

[46] Hegmans A, Berners-Price SJ, Davies MS, Thomas D, Humphreys A, Farrell N. Long range 1,4 and 1,6-interstrand cross-links formed by a trinuclear platinum complex. Minor groove pre-association affects kinetics and mechanism of cross-link formation as well as adduct structure. J Am Chem Soc 2004;126:2166-80.

[47] Berners-Price SJ, Davies MS, Cox JW, Thomas DS, Farrell N. Competitive reactions of interstrand and intrastrand DNA-Pt adducts: A dinuclear-platinum complex preferentially forms a 1,4-interstrand cross-link rather than a 1,2 intrastrand cross-link on binding to a GG 14-Mer duplex. Chem Eur J 2003;9:713-25.

[48] Thomas JO. HMG 1 and 2: architectural DNA-binding proteins. Biochem Soc Trans 2001;29:395-401.

[49] Comess KM, Burstyn JN, Essigmann JM, Lippard SJ. Replication inhibition and translesion synthesis on templates containing site-specifically placed cisdiamminedichloroplatinum(II) DNA adducts. Biochemistry 1992;31:3975-90.

[50] Zamble DB, Mu D, Reardon JT, Sancar A, Lippard SJ. Repair of cisplatin-DNA adducts by the mammalian excision nuclease. Biochemistry 1996;35:10004-13. 
[51] Zhai XQ, Beckmann H, Jantzen HM, Essigmann JM. Cisplatin-DNA adducts inhibit ribosomal RNA synthesis by hijacking the transcription factor human upstream binding factor. Biochemistry 1998;37:16307-15.

[52] Vichi P, Coin F, Renaud JP, Vermeulen W, Hoeijmakers JHJ, Moras D, et al. Cisplatinand UV-damaged DNA lure the basal transcription factor TFIID/TBP. EMBO J 1997;16:7444-56.

[53] Fichtinger-Schepman AMJ, Van der Veer JL, Den Hartog JHJ, Lohman PHM, Reedijk J. Adducts of the antitumor drug cis-diamminedichloroplatinum(II) with DNA: Formation, identification, and quantitation. Biochemistry 1985;24:707-13.

[54] Keck MV, Lippard SJ. Unwinding of supercoiled DNA by platinum ethidium and related complexes. J Am Chem Soc 1992;114:3386-90. 
Table 1. In vitro growth inhibition of human ovarian cisplatin sensitive (A2780) and resistant (A2780cisR) cells, $\mathrm{IC}_{50}(\mu \mathrm{M})^{\mathrm{a}, \mathrm{b}}$

\begin{tabular}{lcc}
\hline & A2780 & A2780 cisR $^{\mathrm{c}}$ \\
\hline cisplatin & $2.8 \pm 0.7$ & $18.6 \pm 0.4(6.6)$ \\
$\mathbf{1}$ & $2.7 \pm 0.7$ & $2.7 \pm 0.1(1)$ \\
$\mathbf{2}$ & $4.8 \pm 2.7$ & $3.6 \pm 1.1(0.75)$ \\
\hline
\end{tabular}

${ }^{\text {a }}$ Drug-treatment period was $72 \mathrm{hr}$.

${ }^{\mathrm{b}}$ Values shown in the table are the means $( \pm$ SEM) of three separate experiments, each conducted with 6 replicates.

${ }^{\mathrm{c}}$ Resistance factor, defined as $\mathrm{IC}_{50}$ (resistant) / $\mathrm{IC}_{50}$ (sensitive), is given in parentheses. 
Table 2. Summary of the effects of complex $\mathbf{1}, \mathbf{2}$ and cisplatin on DNA ${ }^{\text {a }}$

\begin{tabular}{|c|c|c|c|}
\hline & $\mathbf{1}$ & 2 & cisplatin \\
\hline DNA binding $\left(\mathrm{t}_{50 \%}\right)(\mathrm{min})^{\mathrm{b}}$ & $14.9 \pm 0.6$ & $39 \pm 6$ & $120^{c}$ \\
\hline Preferential DNA binding sites ${ }^{\mathrm{d}}$ & G & G & $\mathrm{GG}, \mathrm{AG}^{\mathrm{e}}$ \\
\hline Reduction of EtBr fluorescence & strong & medium & medium \\
\hline Plasmid DNA unwinding angle/adduct & $17^{\circ}$ & $12^{\circ}$ & 110 \\
\hline$\%$ interstrand cross-links/adduct & $48 \pm 4$ & $20 \pm 2$ & \\
\hline
\end{tabular}

${ }^{\text {a }}$ See also Figs. S1 - S4.

${ }^{\mathrm{b}}$ See the text for details.

${ }^{\mathrm{c}}$ Ref. [37].

${ }^{\mathrm{d}}$ Determined by transcription mapping.

${ }^{\mathrm{e}}$ Ref. [53].

${ }^{\mathrm{f}}$ Ref. [54].

${ }^{\mathrm{g}}$ Ref. [38]. 
Figure Captions

Fig. 1 - Structures of the platinum complexes.

Fig. 2 - In vitro DNA repair synthesis assay. Repair synthesis of the extract prepared from the repair-proficient HeLa cell line used as substrates nonmodified pBR322 plasmid and pUC19 plasmid nonmodified or modified at $r_{b}=0.03$ by cisplatin, complex $\mathbf{1}$, and complex 2 . (A) Results of a typical experiment. Top panel, a photograph of the EtBr stained gel; bottom panel, autoradiogram of the gel showing incorporation of $\left[\alpha-{ }^{32} \mathrm{P}\right] \mathrm{dCTP}$. Lanes: 1 , nonmodified pBR322 plus pUC19 plasmids; 2, nonmodified pBR322 plus pUC19 modified by cisplatin; 3, nonmodified pBR322 plus pUC19 modified by 1; 4, nonmodified pBR322 plus pUC19 modified by 2. (B) Incorporation of dCTP into nonmodified or platinated pUC19 plasmid. For all quantifications representing mean values of three separate experiments, incorporation of radioactive material is corrected for the relative DNA content in each band. The radioactivity associated with the incorporation of $\left[\alpha^{32} \mathrm{P}\right] \mathrm{dCTP}$ into DNA modified by cisplatin was taken as $100 \%$. Values shown in the graph are the means $( \pm$ SEM) of three separate experiments, each conducted with 4 replicates.

Fig. 3 - Recognition by HMG-domain proteins of platinated DNA. Affinity of full-length HMGB1 (A) HMGB1 domain A (B), and HMGB1 domain B (C) to nonmodified (control) DNA (lanes noPt) or DNA modified by cisplatin (lanes cisPt), complex 1 (lanes 1) or complex 2 (lanes 2). Lanes M, a protein size marker; lane HMGB1, HMGB1 protein was loaded; lane HMGB1 dom A, HMGB1domain A was loaded. 
Fig. 4 - Recognition by HMGB1 domain B of DNA fragments intrastrand or interstrand crosslinked by complex $\mathbf{1}$. After reaction with $\mathbf{1}$, the DNA was separated by gel electrophoresis so that the fraction F-IEC contained all interstrand cross-linked fragments and the fraction F-IAA contained exclusively platinum adducts formed within one strand of DNA (contained no interstrand CLs, for other details, see the text). Lanes: M, a protein size marker; noPt, control, nonplatinated; F-IAA, intrastrand adducts containing DNA incubated with HMGB1 domain B; F-IEC, interstrand cross-links containing DNA incubated with HMGB1 domain B.

Fig. 5 - The effects of estradiol or estradiol plus progesterone cotreatment on sensitivity of MCF-7 cells towards complexes $\mathbf{1}$ (A), 2 (B) or cisplatin (C) determined by clonogenic assay. MCF-7 cells were cotreated with estradiol $(0.2 \mu \mathrm{M})(\boldsymbol{\Delta})$ or estradiol $(0.2 \mu \mathrm{M})$ plus progesterone $(0.2 \mu \mathrm{M})(\boldsymbol{\nabla})$ with platinum complex for $4 \mathrm{hr}$; $(\square)$, no steroid hormone added. Values shown in the graphs are the means $( \pm$ SEM) of six separate experiments, each conducted with 6 replicates; where error bars are not shown, they were smaller than the symbols. 

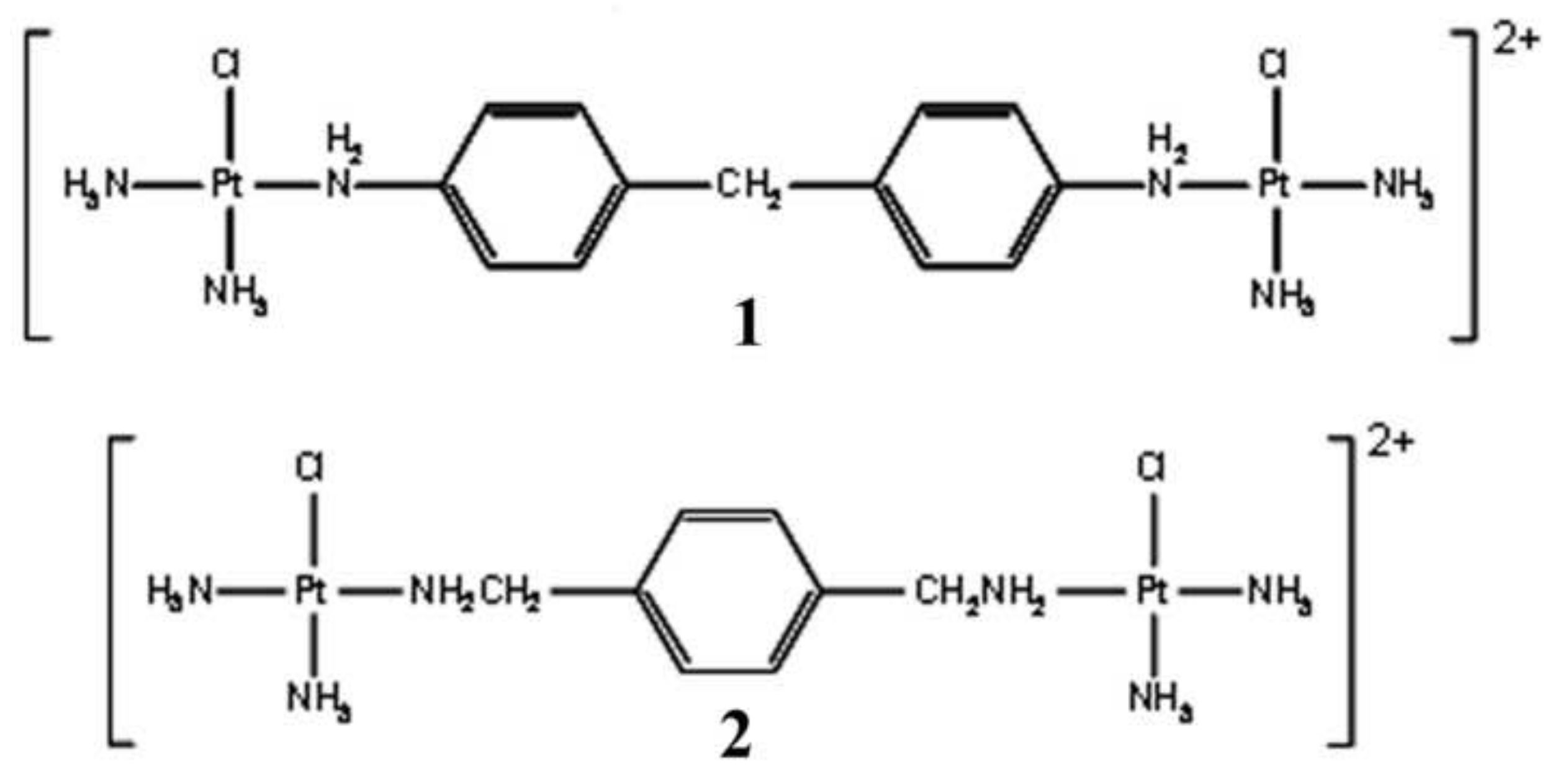

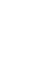

\footnotetext{
$$
\text { . }
$$

.
}

( 
${ }^{32} \mathrm{P}$

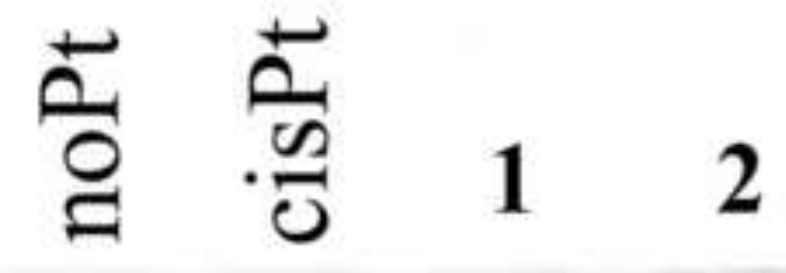

B

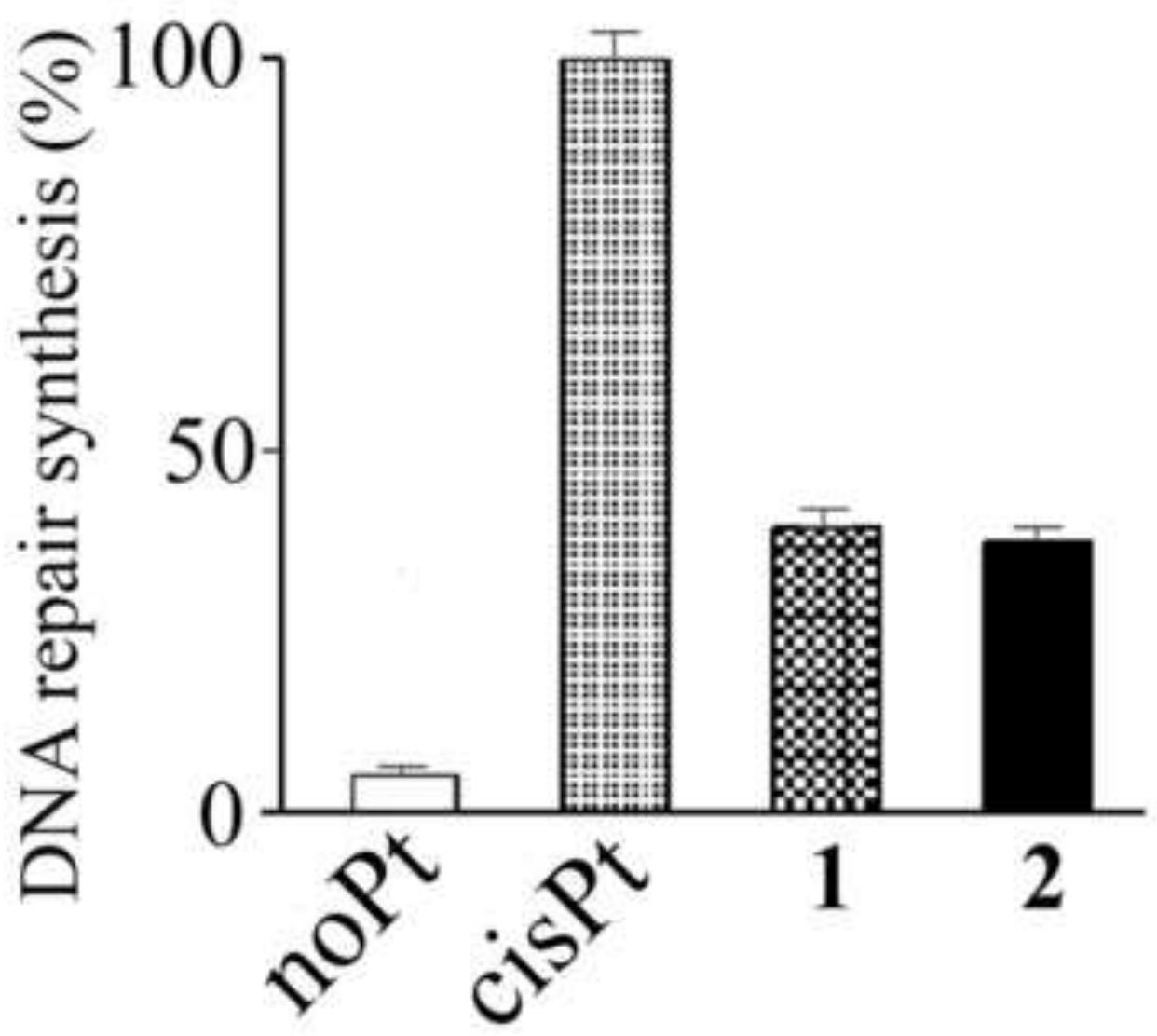

$\mathrm{EtBr}$

lines: $1 \quad 2 \quad 3 \quad 4$ 
A

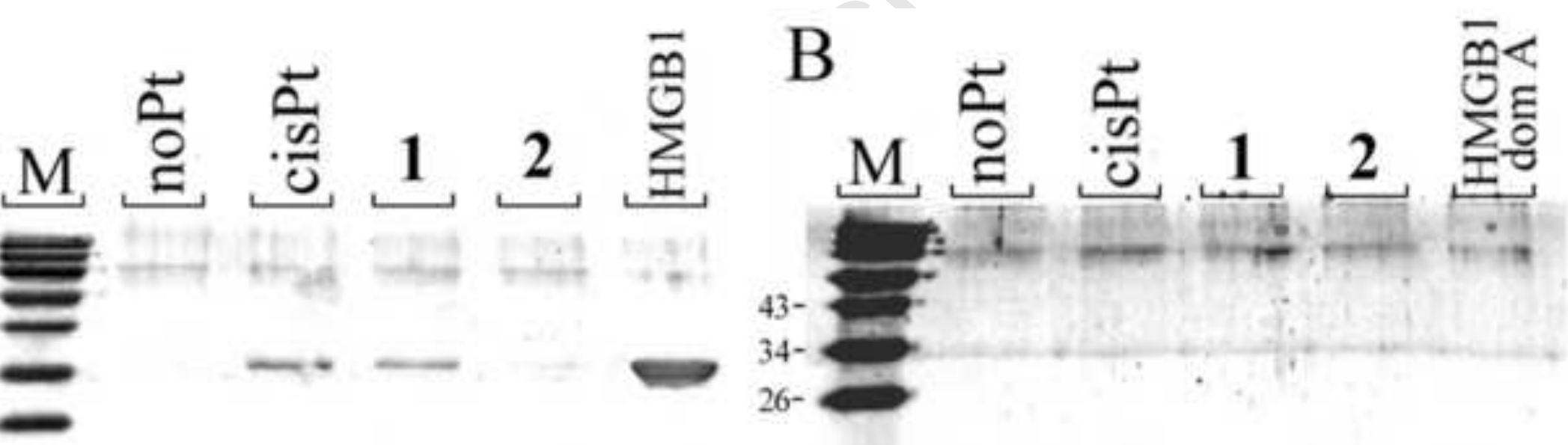

17-

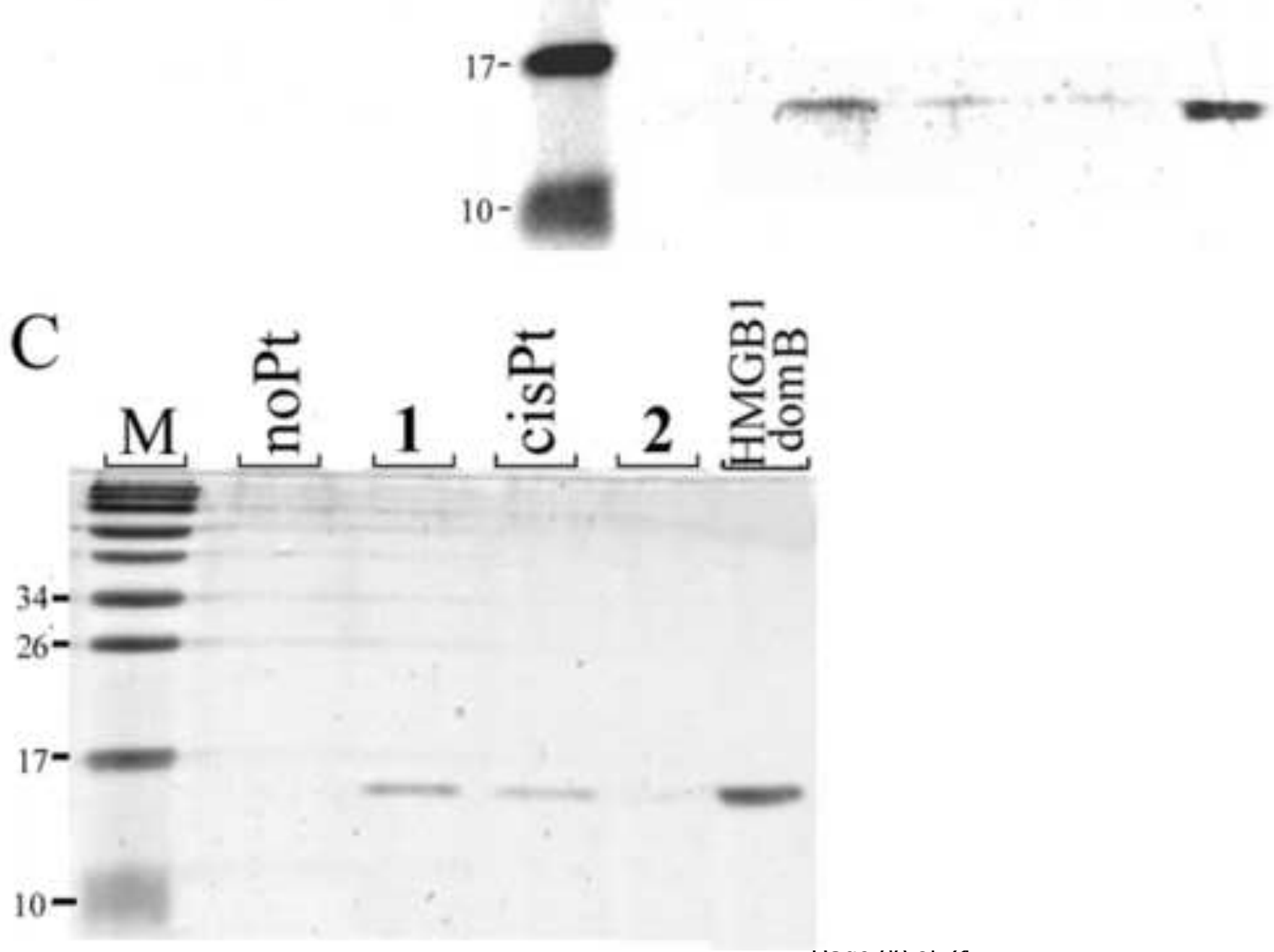




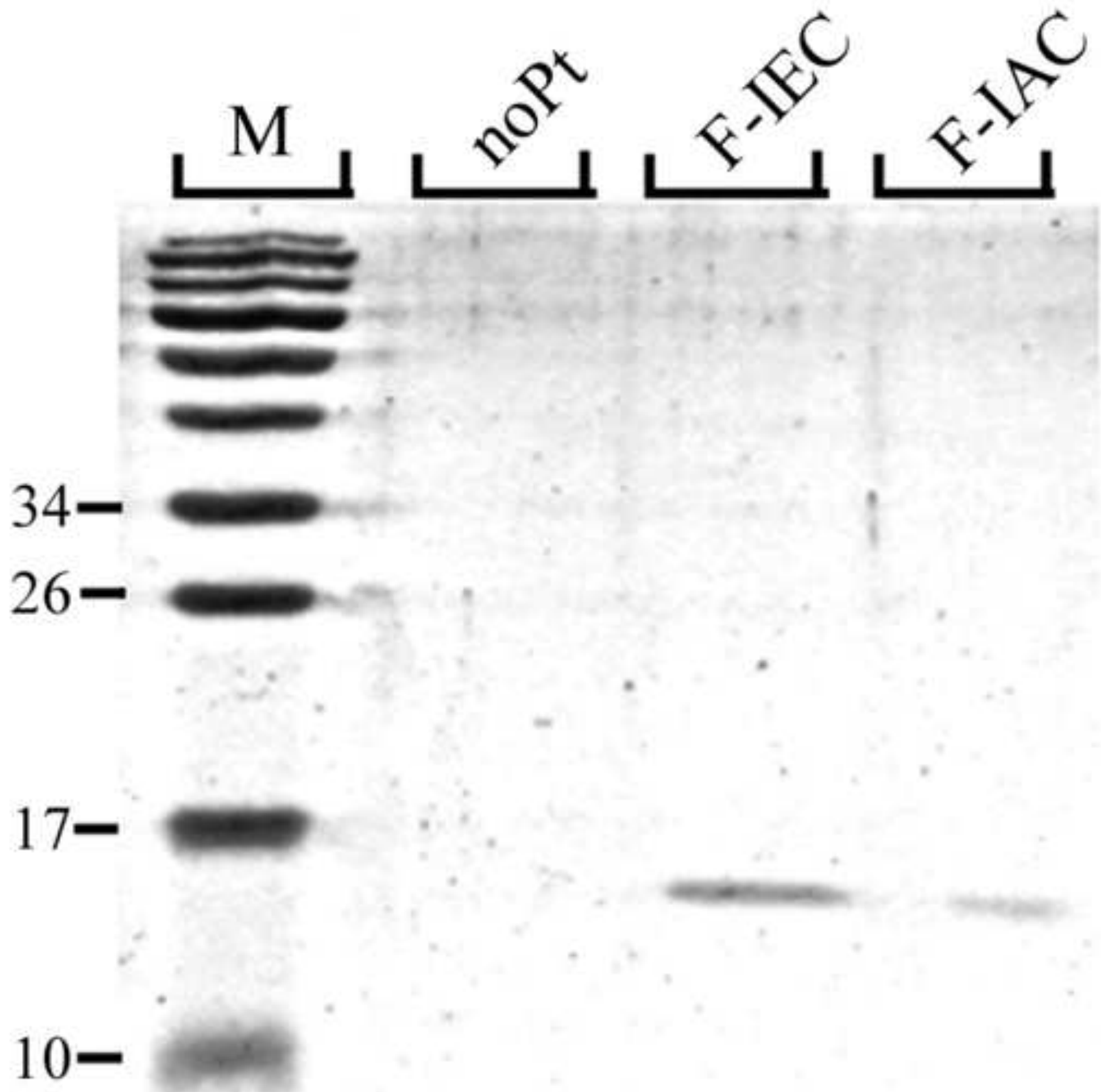

\section{4- \\ 26-}

10-
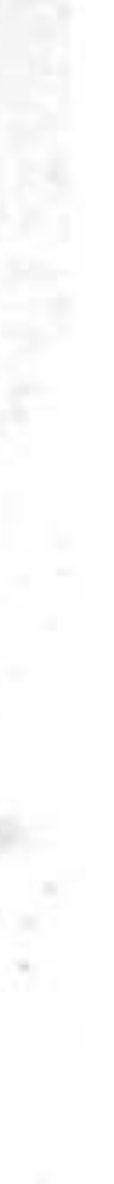

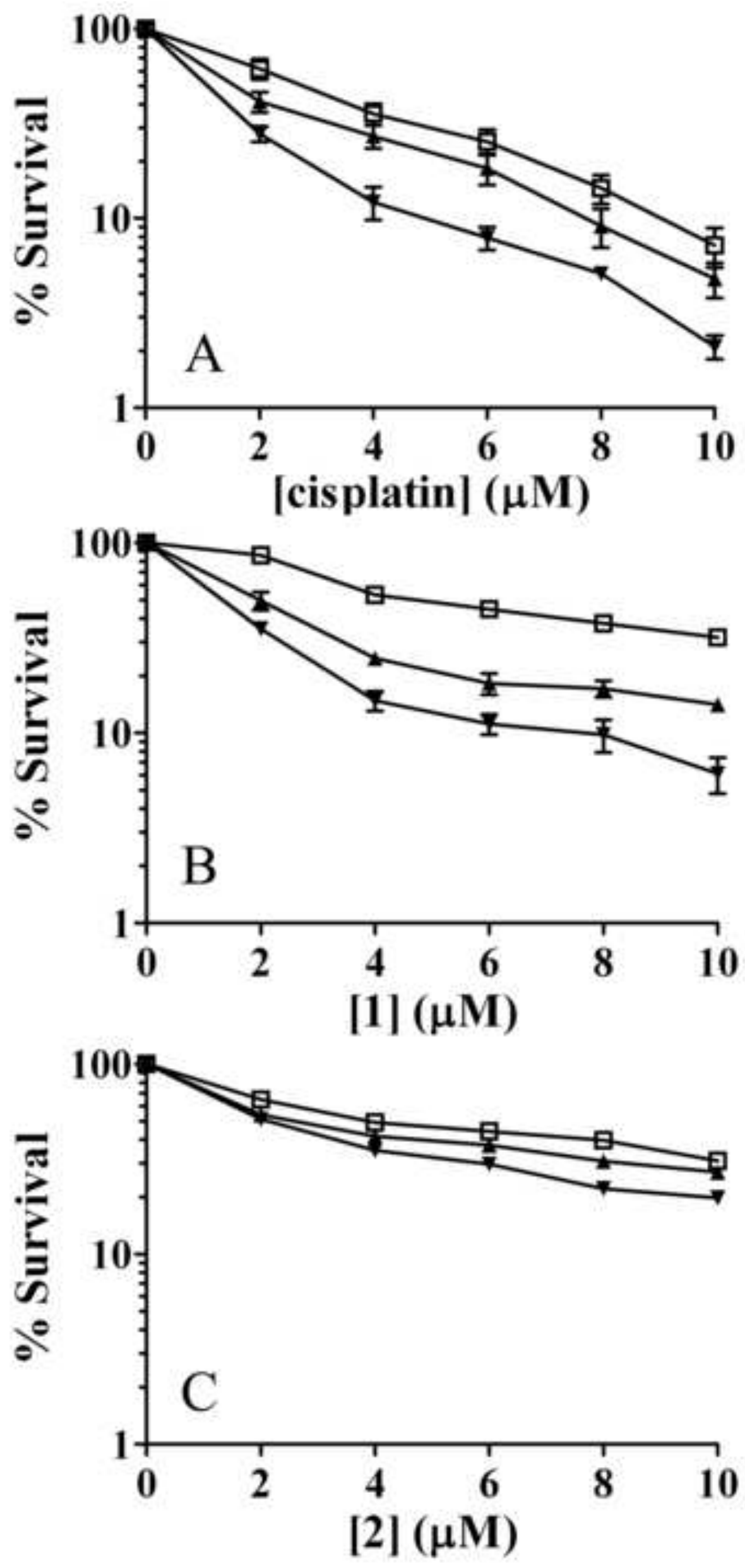